Avaliação do efeito da profilaxia profissional com jato de bicarbonato de sódio sobre o esmalte de dente bovino e do efeito remineralizador da saliva artificial. Estudo in vitro

Helena Zaramella Vono Ribeiro

Dissertação apresentada à Faculdade de Odontologia de Bauru, Universidade de São Paulo, como parte dos requisitos para obtenção do título de mestre em Odontologia, na área de Odontopediatria.

(Edição Revisada) 
Avaliação do efeito da profilaxia profissional com jato de bicarbonato de sódio sobre o esmalte de dente bovino e do efeito remineralizador da saliva artificial. Estudo in vitro

Helena Zaramella Vono Ribeiro

Dissertação apresentada à Faculdade de Odontologia de Bauru, Universidade de São Paulo, como parte dos requisitos para obtenção do título de mestre em Odontologia, área de Odontopediatria.

(Edição Revisada)

Orientador: Prof. Dr. José Eduardo de Oliveira Lima 
Ribeiro, Helena Zaramella Vono

R354a Avaliação do efeito da profilaxia profissional com jato de bicarbonato de sódio sobre o esmalte de dente bovino e do efeito remineralizador da saliva artificial. Estudo in vitro / Helena Zaramella Vono Ribeiro. - Bauru, 2005.

91 p.; il.; $30 \mathrm{~cm}$.

Dissertação (Mestrado) - Faculdade de Odontologia de Bauru. Universidade de São Paulo.

Orientador: Prof. Dr. José Eduardo de Oliveira Lima

Autorizo, exclusivamente para fins acadêmicos e científicos, a reprodução total ou parcial desta dissertação/tese, por processos fotocopiadores elou meios eletrônicos.

Assinatura do autor:

Data: I 


\section{Dados Curriculares}

\section{Helena Zaramella Vono Ribeiro}

Nascimento

Naturalidade

Filiação

$1997-2001$

$2002-2003$

$2003-2005$

Associações
02 de junho de 1980

Bauru - SP

Bernardo Gonzalez Vono

Astrid Zaramella Vono

Curso de graduação em Odontologia na Universidade Paulista, Campus Bauru

Curso de especialização em Dentística Restauradora na Faculdade de Odontologia de Bauru, Universidade de São Paulo

Curso de Pós-Graduação em Odontopediatria, em nível de Mestrado, na Faculdade de Odontologia de Bauru, Universidade de São Paulo

CRO - SP Conselho Regional de Odontologia do Estado de São Paulo

APCD - Associação Paulista dos Cirurgiões Dentistas 


\section{Dedicatória}

Ao meu marido, Evandro Ribeiro Filho, pela compreensão e paciência durante o desenvolver do trabalho, por sempre compartilhar meus momentos, apoiando-me, confortando-me e fazendo sentir-me a mulher mais amada, respeitada e feliz. O meu Amor e orgulho por você é infinito.

Aos meus pais Bernardo Gonzalez Vono e Astrid Zaramella Vono, que com tanto zelo, tanto carinho, tanta preocupação, tanto apoio, tantos conselhos, tanto conforto, tanto Amor, são os melhores professores da principal escola que já freqüentei e onde ainda sou aluna - a "Escola da Vida", e que, além de tudo isso, são também meus grandes professores de Odontologia.

Aos que me dão muita, mas muita alegria: Vó Carmen, Ber, Carmen, Heloísa, Isadora, Rodrigo, Tia Sandra e Clóvis, e, mais recentemente, D. Maria Helena, Sr. Evandro.

A vocês, dedico este trabalho. 


\section{Agradecimentos}

Ao meu orientador "Prof. Dr. José Eduardo de Oliveira Lima", meu muito obrigado pela compreensão demonstrada no desenrolar de todo o curso, sempre com uma palavra amiga e de incentivo, dando-me segurança para vencer as dificuldades das diferentes fases do trabalho, de uma forma que somente quem tem uma experiência profissional e de vida, pode passar aos seus discípulos.

Aos professores da Disciplina de Odontopediatria, do Departamento de Odontopediatria, Ortodontia e Saúde Coletiva, professores doutores Aymar Pavarini, Maria Aparecida de Andrade Moreira Machado, Maria Francisca Thereza Borro Bijella, Ruy César Camargo Abdo e Salete Moura Bonifácio da Silva, que com muita propriedade me passaram seus conhecimentos e me honraram com suas amizades.

Aos colegas Heitor Honório Marques e Prof ${ }^{\mathrm{a}}$. Dra . Daniela Rios pela atenção e disponibilidade em me auxiliar em todos os momentos que precisei, além do carinho com que muito me incentivaram.

À minha colega de mestrado Ana Carolina de Alencar Fraga que com o apoio de uma verdadeira amizade, compartilhou de todos os momentos da execução do trabalho.

Aos demais colegas do Mestrado Tiza, Carol Fraga, Carol Magalhães, Érica, Juliano, Sandra e Vivien, por serem tão especiais e fazerem maravilhosa nossa convivência nesses dois anos. 
Ao pessoal do Doutorado Adriano, Érika, Gladis, Heitor, Marina, Marcelo e Thaís pelo apoio e atenção a mim dispensados.

Aos funcionários da disciplina de Odontopediatria, D. Lia, Lílian, Estela, Fátima e Everton pela gentileza e presteza com que sempre me ajudaram quando precisei.

À Prof ${ }^{a}$. Dr ${ }^{a}$. Marília Afonso Rabelo Buzalaf que com seus conhecimentos muito me auxiliou durante a parte experimental do trabalho, abrindo-me as portas para a utilização dos equipamentos e do laboratório de Bioquímica.

À Thelma e Ovídio do laboratório de Bioquímica pela prontidão em sempre me ajudar.

Ao Departamento de Dentística, Endodontia e Materiais Dentários, em especial ao Prof. Dr. Rafael Lia Mondelli, pelo empréstimo dos equipamentos para a realização do trabalho.

Ao funcionário da disciplina de Endodontia, Edmauro, pela ajuda no corte dos dentes bovinos.

Ao Prof. Dr José Roberto Pereira Lauris, pela orientação e presteza com que realizou a análise estatística dos dados deste trabalho.

Aos funcionários da biblioteca e do setor de pós-graduação da FOBUSP, pela colaboração oferecida.

A todos que, por minha falha, não estão aqui nomeados, mas que também contribuíram para a realização deste trabalho, externo minha gratidão. 


\section{Sumário}

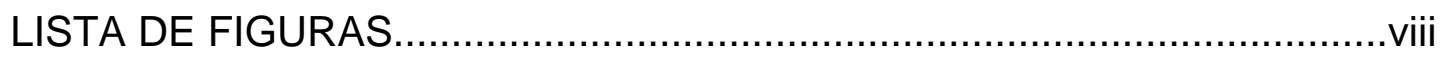

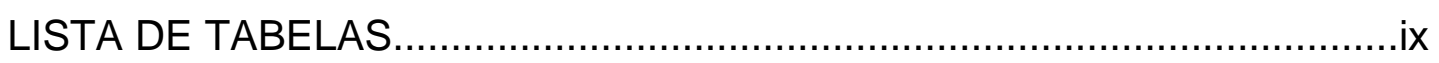

LISTA DE SIGLAS, SÍMBOLOS E PALAVRAS DE LÍNGUA

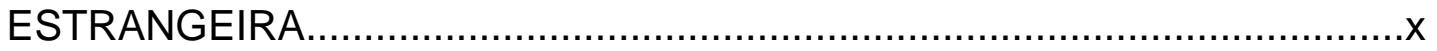

RESUMO

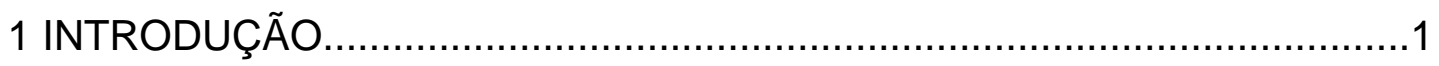

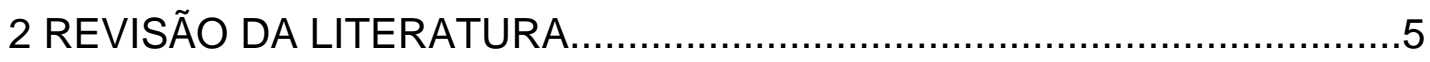

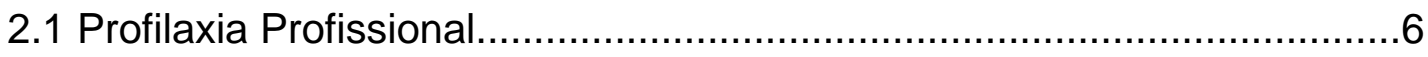

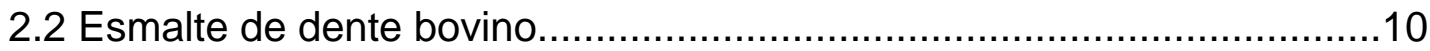

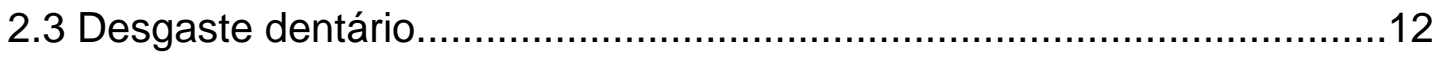

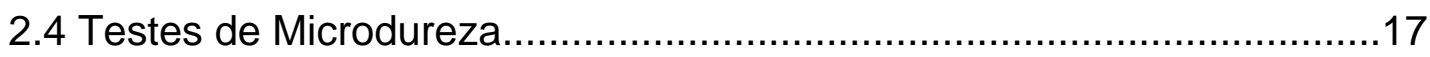

2.5 Remineralização dentária pela saliva .................................................24

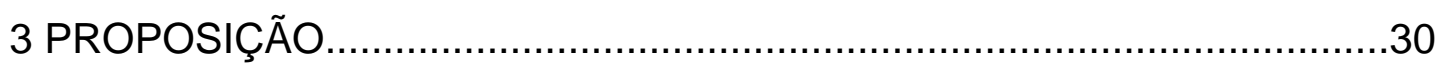

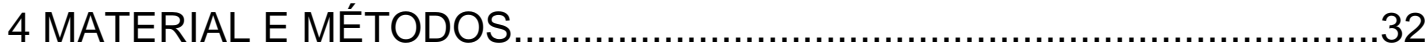

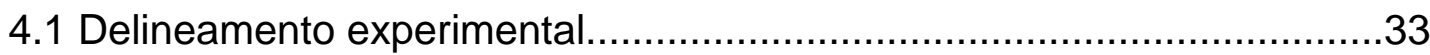

4.2 Obtenção dos blocos de esmalte bovino................................................

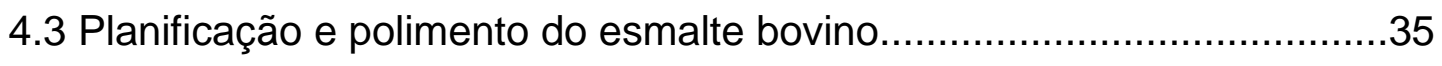

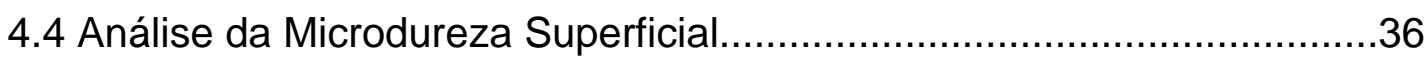

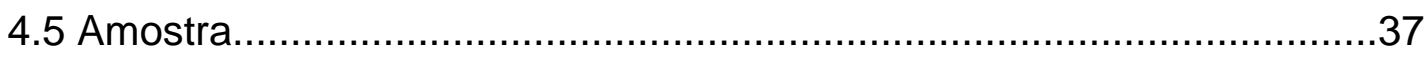

4.6 Tratamento com jato de bicarbonato de sódio.......................................38

4.7 Análise da microdureza superficial após tratamento com jato de

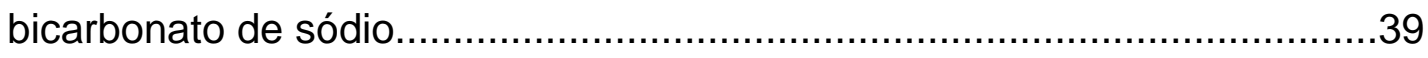

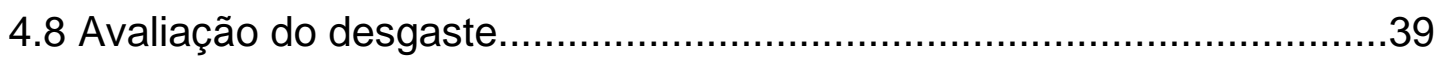


4.9 Tratamento pela saliva artificial..................................................40

4.10 Análise da microdureza superficial após tratamento com saliva...........40

4.11 Avaliação do desgaste após tratamento com saliva...........................41

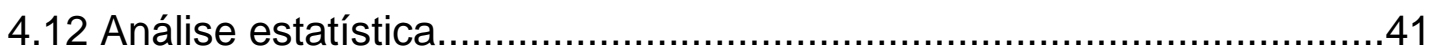

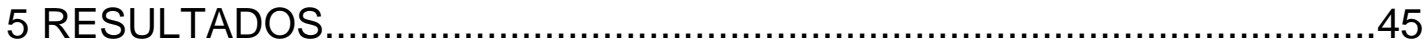

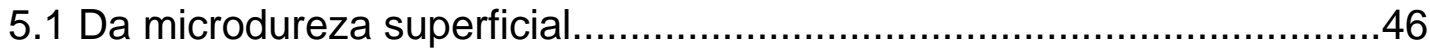

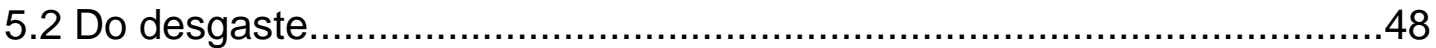

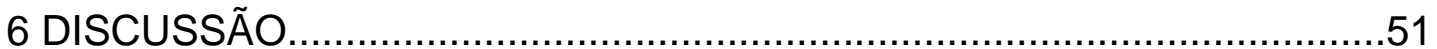

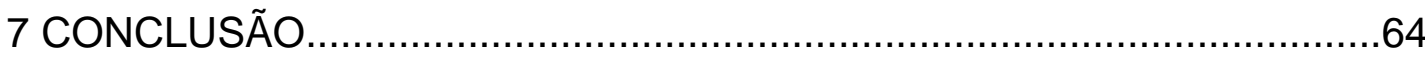

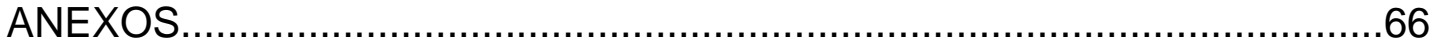

REFERÊNCIAS BIBLIOGRÁFICAS ................................................

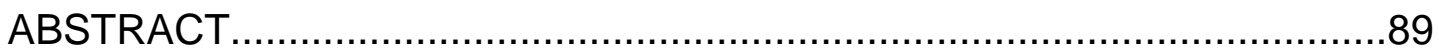




\section{Lista de Figuras}

FIGURA 1 - Delineamento experimental............................................42

FIGURA 2 - Aparelho de corte de precisão.......................................43

FIGURA 3 - Espécime obtido através da coroa seccionada.....................43

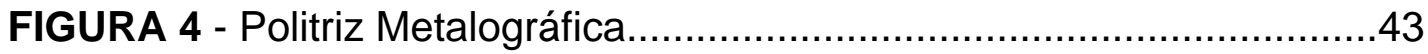

FIGURA 5 - Espécime antes e após a planificação da dentina...................43

FIGURA 6 - Microdurômetro............................................................43

FIGURA 7 - Penetrador diamantado tipo KNOOP ................................43

FIGURA 8 - Impressão do penetrador...........................................44

FIGURA 9 - Aplicação do esmalte para unha no espécime.......................44

FIGURA 10 - Rugosímetro....................................................44

FIGURA 11 - Ponta apalpadora do Rugosímetro......................................44

FIGURA 12 - Representação do desgaste da superfície testada...............44

FIGURA 13 - Gráfico dos valores médios da microdureza superficial do esmalte (KHN) antes e após a simulação da profilaxia e após a imersão em saliva artificial nos diferentes tempos de tratamento.

FIGURA 14 - Gráfico dos valores das médias do desgaste do esmalte ( $\mu \mathrm{m})$ após a simulação da profilaxia e após a imersão em saliva artificial em diferentes tempos de tratamento 


\section{Lista de Tabelas}

TABELA 1 - Valor da média em KHN, da microdureza superficial inicial, após a simulação da profilaxia e após a imersão em saliva artificial nos diferentes tempos de tratamento - Análise de Variância.

TABELA 2 - Comparação entre os valores médios de microdureza superficial - Teste de Tukey..... 48

TABELA 3 - Valores da média em $\mu$ m, do desgaste após a simulação da profilaxia e após a imersão em saliva artificial nos diferentes tempos de tratamento - Análise de Variância. .48

TABELA 4 - Comparação entre os valores médios do desgaste Teste de Tukey .50 


\section{Lista de siglas, símbolos e palavras de língua estrangeira}

$\%=$ por cento

* = diferença estatisticamente significante

${ }^{\circ} \mathrm{C}=$ graus centígrados

$\mathrm{C}=$ constante aplicada na fórmula para o cálculo de dureza Knoop

$\mathrm{c}=$ carga usada no microdurômetro

$\mathrm{Ca}=$ cálcio

$\mathrm{cm}=$ centímetro

$\mathrm{d}=$ comprimento da diagonal maior da impressão

$\mathrm{G}=$ grupo

$\mathrm{g}=$ gramas

in situ (latim) = em sítio, no local

in vitro $($ latim $)=$ em laboratório

in vivo $($ latim $)=$ em ser vivo

$\mathrm{Kg}=$ quilograma

$\mathrm{KHN}=$ número de dureza Knoop

$\mathrm{KHz}=$ quilo hertz

$\mathrm{Kg} / \mathrm{mm}^{2}$ = quilograma por milímetro quadrado

$\mathrm{KL}=$ quilo litro

$\mathrm{M}=$ molar

$\mathrm{MF}=$ média final

$\mathrm{Mol} / \mathrm{L}=\mathrm{mol}$ por litro

$\mathrm{mL}=$ mililitros

$\mathrm{mm}=$ milímetros

$\mathrm{mm}^{2}=$ milímetro quadrado 
$\mathrm{N}$ = número de cada espécime

$\mathrm{pH}=$ potencial hidrogêniônico

ppm = parte por milhão

$\mu \mathrm{m}=$ micrômetro

$\mu \mathrm{m} / \mathrm{L}=$ micrômetro por litro

$\mu \mathrm{m} / \mathrm{mm}^{2}$ = micrômetro por milímetro quadrado

$\mathrm{rpm}=$ rotações por minuto

$s=$ segundos 
Resumo 


\section{Resumo}

O objetivo do trabalho foi avaliar in vitro as alterações da microdureza (M) e do desgaste (D) provocadas pelo jato de bicarbonato de sódio em esmalte bovino hígido e o posterior efeito remineralizador da saliva artificial em diferentes períodos de tempo. Utilizaram-se 15 espécimes de esmalte $(4,0 \mathrm{~mm} \times 4,0 \mathrm{~mm})$ que constituíam os grupos MI (sem tratamento), MII (tratamento com jato de bicarbonato de sódio), MIII (tratamento com jato de bicarbonato de sódio e imersão em saliva por uma hora), MIV (tratamento com jato de bicarbonato de sódio e imersão em saliva por 24 horas), MV (tratamento com jato de bicarbonato de sódio e imersão em saliva por sete dias) e DI (tratamento com jato de bicarbonato de sódio), DII (tratamento com jato de bicarbonato de sódio e imersão em saliva por uma hora), DIII (tratamento com jato de bicarbonato de sódio e imersão em saliva por 24 horas) e DIV (tratamento com jato de bicarbonato de sódio e imersão em saliva por sete dias). Após o tratamento com jato de bicarbonato de sódio, os espécimes ficaram imersos em $20 \mathrm{ml}$ de saliva artificial, armazenados individualmente em recipientes plásticos tampados, em estufa, a $37^{\circ} \mathrm{C}$, pelos tempos mencionados. A saliva era renovada diariamente. Foram realizados testes de microdureza utilizando-se um microdurômetro e testes de desgaste por meio de um rugosímetro. Os dados foram avaliados pela Análise de Variância a um critério e pelo Teste de Tukey. O valor das médias da microdureza, em KHN, nos grupos MI, MII, MIII, MIV e MV foram 359,80; 335,46 ; 369,20; 377,73 e 341,86; respectivamente, enquanto que os valores médios, em $\mu \mathrm{m}$, do desgaste para o grupo DI, DII, DIII e DIV foram 0,564; 0,519; 0,441 e 0,428, respectivamente. Concluiu-se que: o jato de bicarbonato de sódio causou um desgaste e uma diminuição da microdureza superficial; a saliva promoveu o retorno da microdureza superficial à condição inicial e reduziu o desgaste; o efeito reparador da saliva sobre as alterações na microdureza superficial já ocorreu com uma hora de 
tratamento, não havendo diferença estatisticamente significante do efeito obtido com 24 horas; o melhor efeito reparador da saliva sobre o desgaste ocorreu com 24 horas de tratamento. 


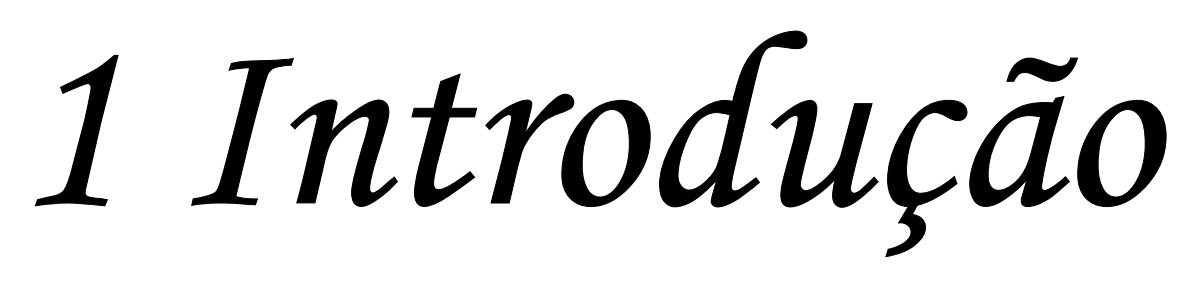




\section{Introdução}

No desenvolvimento da cárie dentária, a placa bacteriana desempenha um papel essencial. A placa se forma pela aderência das bactérias bucais à película adquirida, que é uma membrana delicada, formada pela adsorção de proteínas específicas da saliva na superfície do esmalte $^{68},{ }^{87}$. As bactérias acidogênicas da placa, principalmente Streptococcus mutans e lactobacilos, produzem ácidos orgânicos pelo metabolismo de substratos carboidráticos ${ }^{8,38,87}$. Os ácidos em contato com a superfície do dente promovem a perda de minerais que leva à dissolução da estrutura inorgânica do esmalte, formando a cárie. Assim, não havendo placa, não há cárie.

Tanto o método químico quanto o mecânico de controle da placa têm sido enfatizados na odontologia moderna.

Comparativamente ao controle químico da placa, a remoção mecânica apresenta a vantagem de ter um menor custo e ser mais acessível à população ${ }^{8}$. Além disso, no controle químico da placa, os agentes antibacterianos utilizados com freqüência podem alterar a microbiota da cavidade bucal e do trato gastrintestinal, com desenvolvimento de microrganismos resistentes e ou permitindo infecções oportunistas ${ }^{86}$.

A escovação e o uso do fio dental constituem métodos de remoção mecânica da placa dentária, cujas técnicas podem ser executadas pelo próprio paciente ${ }^{49}$. São métodos excelentes e indispensáveis, porém, principalmente em crianças, insuficientes, quando não complementados periodicamente por uma atuação profissional. Isto porque a escovação e o uso do fio dental estão na dependência da disposição dos pacientes em realizá-los e estes nem sempre compreendem o quanto a manutenção da higiene bucal é fundamental para evitar o início e a progressão da cárie e doenças periodontais. Além do mais, é preciso uma certa habilidade manual para dominar as técnicas, destreza esta que pode ser falha em alguns 
indivíduos e principalmente em crianças por seu desenvolvimento motor imaturo $^{49}$. Assim, para se ter mais segurança de que não haja placa aderida aos dentes desses pacientes, é necessário que sua remoção mecânica seja realizada com uma certa freqüência pelo profissional, atividade esta conhecida por profilaxia.

A profilaxia pode ser realizada com taça de borracha ou escova de Robinson, acionada por um micromotor e uma substância de certa abrasividade como dentifrícios ou pastas preparadas para esta finalidade. Esse procedimento é facilmente realizável no consultório odontológico, porém, sua eficácia deixa a desejar na remoção de placa de sulcos e fissuras e nas superfícies proximais dos dentes ${ }^{82}$.

Um outro método de profilaxia profissional consiste no emprego de um jato controlado de ar, água e partículas de bicarbonato de sódio, sob pressão, que age promovendo uma remoção mecânica da placa e ainda um polimento das superfícies dentárias ${ }^{50}, 63,74,83$. É mais vantajoso que a profilaxia com taça de borracha ou escova de Robinson, pois requer menor tempo de trabalho ${ }^{74}$, não gera calor e é menos desconfortável para o paciente em dentes com sensibilidade, bem como é bastante efetivo na presença de aparelhos ortodônticos ${ }^{50,63}$ e remove a placa de sulcos e fissuras e das superfícies proximais dos dentes ${ }^{50,64}$. Porém, devido à localização cervical da placa, muitas vezes a gengiva é traumatizada ${ }^{58,83}$, mas a irritação geralmente não é considerada clinicamente significante ${ }^{58}$.

Ao se realizar a profilaxia profissional ocorre uma remoção de estrutura superficial dentária. Vários trabalhos ${ }^{20,53,55,61,85,88}$ quantificaram o desgaste ocorrido em esmalte hígido, mas não há um consenso quanto aos resultados, embora se saiba que o desgaste é maior quando a profilaxia é feita sobre esmalte previamente desmineralizado ${ }^{16,29,40,91}$. Também, faltam informações quanto às conseqüências desse procedimento sobre a microdureza superficial do esmalte.

Quando há uma perda de mineral no dente ocorre uma remineralização por ação da saliva $2,43,66,78$ que contendo em sua 
composição os principais componentes da estrutura dentária como cálcio e fosfato tem uma ação protetora do esmalte e da dentina ${ }^{51}$.

O papel remineralizador da saliva é potencializado pela presença de flúor na cavidade bucal ${ }^{56,62}$. Contudo, a ingestão de pequenas doses diárias de flúor durante o período de formação dos dentes pode resultar em fluorose dentária e quanto maior a dose de flúor ingerida no período de 11 meses a sete anos de idade mais severa será a alteração67, 80 . Assim, apesar do relevante papel que o flúor apresenta, com seu efeito sinérgico, no processo de remineralização, é preciso estar atento para o fato de que crianças pequenas não possuem domínio da musculatura peribucal, o que dificulta a eliminação de resíduos do veículo do flúor usado ${ }^{81}$.

O benefício advindo do controle da placa para a prevenção da cárie dentária é indiscutível, porém, vemos pelo exposto que:

- $\quad$ a remoção mecânica da placa pelo profissional promove um certo desgaste da superfície do esmalte, cuja quantificação não está completamente esclarecida;

- faltam informações sobre o que ocorre com a microdureza do esmalte submetido à profilaxia;

- $\quad$ as alterações do esmalte oriundas da profilaxia podem ser minimizadas pelo poder remineralizador da saliva, mas ainda é questionável o quanto de reparação ocorre e em que espaço de tempo ela acontece.

Assim, esse campo para pesquisa permanece aberto e o presente trabalho tem a intenção de contribuir para melhor compreensão desses aspectos. 


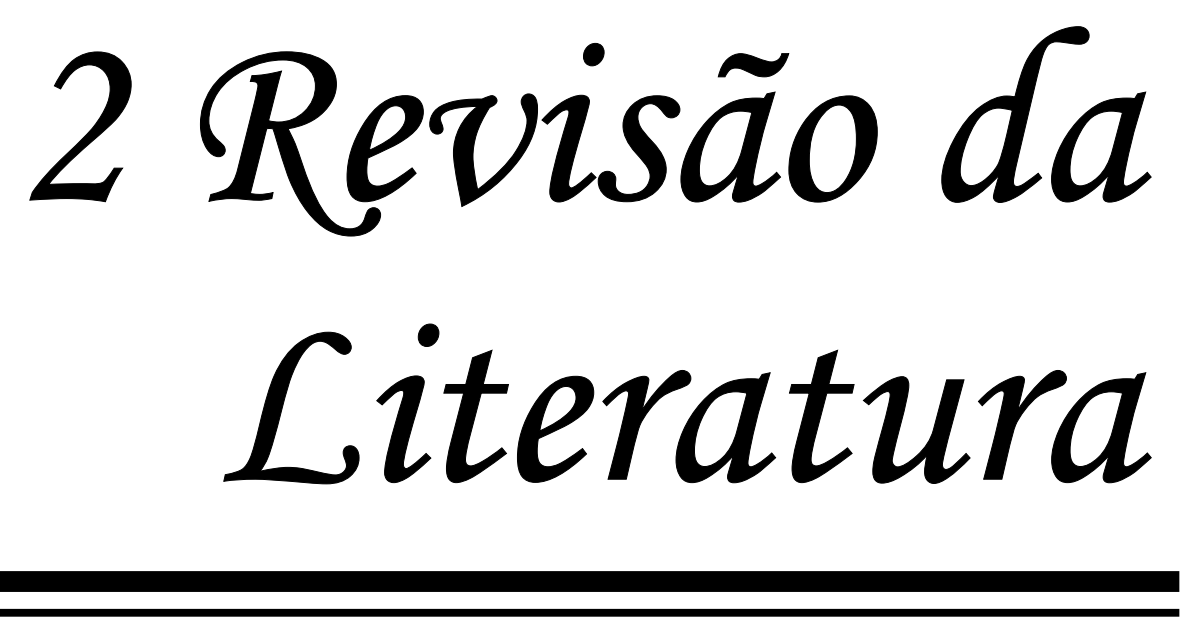




\section{Revisão da Literatura}

\subsection{Profilaxia Profissional}

AXELSSON; LINDHE; WASEBY ${ }^{13}$ (1976) realizaram uma pesquisa com 164 crianças, de 13 a 14 anos de idade, durante um período de dois anos, para comparar a eficácia de diferentes procedimentos de controle de placa sobre a cárie e gengivite. Concluíram que a instrução de higiene bucal e a profilaxia profissional com instrumentos de limpeza mecânica, realizada a cada duas semanas, reduziu a freqüência de gengivite e preveniu a cárie. Com a adição de bochechos de flúor MPF a 2\% a esse tipo de tratamento não houve melhora nos índices de cárie. Com a substituição da profilaxia por aplicação tópica de gel clorexidina a $0,5 \%$ a placa supragengival não foi removida nem houve diminuição de gengivite e de cárie.

PRIMOSCH $^{72}$ (1980) chamou a atenção para o fato de que a profilaxia, realizada com taça de borracha e pasta profilática, ao promover o polimento da superfície dentária remove, ao mesmo tempo, uma porção da estrutura superficial do esmalte. O autor comparou o efeito dessa remoção à perda mineral que ocorre em uma lesão inicial de cárie. Ainda, acrescentou que o procedimento profilático é estressante e traumático para o paciente, recomendando que o dentista utilize seu tempo para motivar e orientar o paciente para realizar a escovação dos dentes em substituição à profilaxia profissional.

BELLINI; ARNEBERG; VON DER FEHR ${ }^{15}$ (1981), revendo a literatura, constataram que o controle profissional da placa é efetivo em todas as superfícies dos dentes, sendo mais indicado para a prevenção da cárie do que o método de auto-remoção. Salientaram que o mais importante é a qualidade da remoção da placa do que sua realização diária. No entanto, afirmaram que é plenamente justificável a higiene bucal feita pelos 
pacientes, pois, se não é a medida mais eficiente no controle à cárie, traz bons resultados na prevenção dos distúrbios periodontais.

WEAKS et al. ${ }^{83}$ (1984) realizaram procedimentos para remoção de placa em 53 pacientes, sendo que num lado da arcada foi usado o jato de bicarbonato de sódio e no outro a taça de borracha com pasta profilática. Observaram que ocorreram pequenos traumas na gengiva pelos procedimentos, com índice maior para o jato de bicarbonato sendo que, após seis dias, a condição retornava praticamente ao normal. Os autores concluíram que o jato de bicarbonato removeu placa e manchas em menor tempo e de forma melhor do que a taça de borracha.

LIMA; VERRI ${ }^{50}$ (1984) empregaram o jato de bicarbonato de sódio para remover a placa dentária em pacientes com as seguintes condições: três com muita placa e gengivite generalizada (seis profilaxias); uma com GUNA (duas profilaxias); dois com aparelhos ortodônticos fixos (uma profilaxia); dois com idades de cinco a seis anos, com grande quantidade de placa (uma profilaxia). Os pacientes foram acompanhados durante três semanas. O tratamento removeu a placa das superfícies vestibulares, linguais e proximais, bem como nas fossas e fissuras dos dentes. Houve melhora significativa da gengivite inicial e início da recuperação do epitélio nas áreas de pseudomembranas dos pacientes com GUNA. Recomendaram o uso do jato de bicarbonato de sódio para pacientes de ortodontia e em programas de prevenção antes da aplicação tópica de flúor.

NUTTI SOBRINHO; LIMA; WATANABE64 (1985) aplicaram o jato de bicarbonato de sódio, por 30 segundos, em 16 dentes humanos. Alguns apresentavam bolsas profundas, outros restaurações de amálgama ou metalocerâmicas com muita placa, outros tinham coroas provisórias de acrílico auto polimerizáveis, havendo também dentes semi-irrompidos, sem cárie e sem contato com o antagonista. Em todos eles foi constatado pela microscopia eletrônica de varredura que a placa dentária foi totalmente eliminada, inclusive nas fossas e fissuras.

NUTTI SOBRINHO et al. ${ }^{63}$ (1986) avaliaram, por meio de microscopia eletrônica de varredura, a presença ou não de placa nas superfícies internas 
e externas de bandas ortodônticas, removidas de 15 pacientes jovens, em final de tratamento ortodôntico. As bandas dos pacientes que receberam uma profilaxia com jato de bicarbonato de sódio antes da sua remoção estavam livres de placa dentária. Já, as bandas que foram removidas sem a profilaxia prévia estavam cheias de placas nas superfícies examinadas. Sugeriram a profilaxia periódica de pacientes em tratamento ortodôntico e afirmaram que o jato de bicarbonato de sódio promoveu uma limpeza completa em dentes e metais.

MISHKIN et al. ${ }^{58}$ (1986) submeteram 21 indivíduos com gengiva saudável, ou com índices baixos de gengivite, a procedimentos de remoção de placa pela aplicação de jato de bicarbonato de sódio em um lado da boca e pela taça de borracha com pasta profilática do outro. Imediatamente após o tratamento houve irritação gengival causada pelo jato de bicarbonato de sódio que, no entanto, não foi clinicamente significante. Após sete e 21 dias dos tratamentos, não houve diferenças estatisticamente significantes, nos efeitos do trauma gengival causados por ambos os métodos de profilaxia.

DE SPAIN; NOBIS ${ }^{25}$ (1987) compararam a profilaxia com jato de bicarbonato com a realizada com taça de borracha em locais diferentes da boca de 19 indivíduos. Exames realizados 1, 4, 12 e 24 semanas após a profilaxia mostraram não haver diferença estatisticamente significante entre os dois métodos quanto às respostas gengivais e ao reacúmulo de manchas, placa e cálculo supragengival.

HOLMEN et al. ${ }^{39}$ (1988) em um estudo in vivo com 14 crianças, que possuíam um par de pré-molares homólogos indicados para exodontia, por motivos ortodônticos, nos quais foram cimentadas bandas, de forma que houvesse acúmulo de placa no local por um período de cinco semanas. Um dente de cada indivíduo ficou com a banda cimentada por todo o período (controle) e o outro teve a banda removida semanalmente (teste). Nesta ocasião, metade destes dentes teve a placa removida com taça de borracha e pasta profilática e a outra metade por bolinha de algodão embebida em água, antes da banda ser novamente cimentada no dente. Após as cinco semanas os dentes foram extraídos e pela análise com microscópio 
eletrônico de varredura e microscópio de luz polarizada observaram que houve uma desmineralização visível em todos os dentes dos 14 indivíduos, mas que a remoção regular da placa, independentemente do método utilizado, suprimiu a atividade bacteriana e impediu o desenvolvimento da cárie.

STRAND; RAADAL $^{82}$ (1988) compararam o efeito da profilaxia na superfície oclusal feita com jato de bicarbonato de sódio na distância de 1 a $5 \mathrm{~mm}$ por 1 minuto com a realizada com taça de borracha e pedra-pomes acionada a 4000rpm por 1 minuto. Cada tratamento foi realizado em nove pré-molares, imediatamente antes de serem extraídos, para posterior avaliação pela microscopia eletrônica de varredura. O sistema que utilizou o jato de bicarbonato de sódio limpou melhor as superfícies oclusais, pois a taça de borracha não tem acesso aos sulcos e fissuras da região testada.

AXELSON; LINDHE; NYSTRÖM ${ }^{12}$ (1991) desenvolveram um programa preventivo de cárie e de problemas periodontais com 15 anos de acompanhamento, que foi concluído em 317 pacientes. O programa baseouse no controle profissional da placa e aplicação tópica de flúor. Todos os indivíduos foram inicialmente submetidos à raspagem e polimento radicular, bem como a todo tratamento restaurador necessário e depois receberam atenção profissional uma ou duas vezes ao ano, conforme a necessidade. Ao exame final, os pacientes mostraram uma baixa incidência de cárie e praticamente nenhuma perda de suporte periodontal. Concluíram que o uso diário de flúor e o controle mecânico profissional periódico da placa previnem efetivamente a recorrência de distúrbios dentários e periodontais.

LIMA $^{49}$ (1992) apresentou o resultado de um programa preventivo desenvolvido em seu consultório particular com 178 crianças de 3 a 14 anos de idade, durante cinco anos. O programa consistiu-se de remoção mecânica profissional mensal da placa com jato de bicarbonato de sódio, associada à escovação controlada e supervisionada no lar, orientação de alimentação e fluorterapia. Houve um controle efetivo da cárie dentária: no primeiro ano a incidência foi de 0,02 cárie/dente e 0,004 cárie/superfície e no final do programa 0,001 cárie/dente e 0,0004 cárie/superfície. 
RAMAGLIA et al. ${ }^{74}$ (1999) realizaram profilaxia com taça de borracha e pedra-pomes em um hemiarcada e com jato de bicarbonato de sódio na outra de 62 pacientes. Houve redução significativa no índice de placa com as duas técnicas empregadas. O jato de bicarbonato de sódio foi mais rápido e mais eficaz para a remoção de manchas.

\subsection{Esmalte de dente bovino}

ARENDS; SCHUTHOF; JONGELBLOED ${ }^{6}$ (1980) em um estudo no qual mediram a dureza do esmalte de dentes humanos e bovinos, que apresentavam lesões de cárie artificiais, concluíram que quanto maior a profundidade da lesão, maior foi o comprimento de impressão. Estas foram produzidas por um penetrador KNOOP, com carga de 50, 100, 200 e 500g, por 10 segundos. Como as lesões eram maiores no esmalte bovino, deduziram que haja uma maior porosidade deste esmalte.

FEATHERSTONE; MELLBERG ${ }^{28}$ (1981) observaram os padrões de formação de lesões de cárie artificial em blocos de esmalte decíduo, humano e bovino, bem como em permanente humano, bovino (polido e não polido) e ovino. A leitura em microscópio, das coroas cortadas e coradas com rodoamina $6 \mathrm{G}$ a $1 \%$ em etanol, mostrou que a cárie progrediu mais rápido (uma vez e meia) no esmalte decíduo que no permanente, tanto bovino quanto humano. As lesões em esmalte bovino, polido e não polido, e em esmalte de ovinos evoluíram três vezes mais rápido que em esmalte humano.

BUSKES $^{17}$ (1985) constatou através da avaliação da microdureza superficial KNOOP, que o grau de desmineralização de fragmentos polidos de incisivos centrais bovinos foi maior que de pré-molares humanos, quando ambos foram submetidos a uma mesma solução ácida, por um período de cinco dias.

MANNING, EDGAR ${ }^{54}$ (1992), revendo a literatura sobre a metodologia empregada para experimentos in situ de desmineralização e 
remineralização, consideraram que o dente bovino pode ser utilizado para pesquisas em odontologia. Como substrato, apresenta pouca variabilidade comparativamente ao esmalte humano, principalmente quando se remove 100 a $200 \mu \mathrm{m}$ de sua superfície externa. Pela sua superfície ser muito reprodutível, se prestou muito bem para ensaios de microdureza.

MELLBERG $^{57}$ (1992), em trabalho de revisão de literatura sobre substratos utilizados em estudos in situ de atividade cariogênica e anticariogênica, considerou que o esmalte humano é o substrato de escolha. Porém, ressaltou que ele tem como desvantagem a pouca disponibilidade em quantidade e qualidade, bem como o fato de não apresentar uma superfície plana ampla e sofrer influência da idade. Já, o dente bovino é obtido facilmente em quantidade em boas condições, apresenta superfícies planas amplas e sua composição é menos variável que a do esmalte humano, por estar menos exposto a altas concentrações de flúor. Ainda, o esmalte bovino não sofre desafios cariogênicos, o que determina uma resposta experimental mais homogênea. Sendo mais poroso, a taxa de formação e de difusão de lesões é mais rápida que no esmalte humano. Informou também que o índice de formação de lesões no esmalte bovino permanente é muito mais próximo ao índice de formação de cárie no dente decíduo humano.

COLLYS et al. $^{21}$ (1992) realizaram testes de dureza superficial KNOOP em esmalte humano e bovino, antes e após eles serem desmineralizados em soluções ácidas. Os comprimentos das impressões foram maiores no esmalte bovino que nos humanos.

ZERO $^{89}$ (1995), em detalhada revisão sobre modelos de cárie in situ descreveu a respeito do substrato, humano ou bovino, e declarou que seu laboratório utiliza esmalte bovino. Explica que esse esmalte é mais poroso, desmineraliza mais rápido, podendo ser uma alternativa aceitável ao esmalte humano.

OESTERLE et al. ${ }^{65}$ (1998) avaliaram o uso de esmalte de incisivos decíduos e permanentes bovinos e de dentes superiores permanentes humanos em estudos de adesividade. Comentaram que o esmalte bovino é 
de fácil obtenção e apresenta microestrutura similar ao humano, e relataram que, no estudo, a força de adesão no esmalte bovino decíduo foi $21 \%$ a $44 \%$ mais fraca que no esmalte humano. Observaram ainda que a força de adesão no esmalte bovino decíduo foi significantemente maior que no permanente bovino. A conclusão foi que incisivos bovinos podem ser usados com sucesso em estudos de adesividade ao esmalte, e serem reusados algumas vezes sem que se afetem os resultados.

AMAECHI; HIGHAM; EDGAR $^{4}$ (1999) testaram a influência da temperatura, tempo de exposição a um suco de laranja e tipo de esmalte no desenvolvimento e progressão da erosão dentária, pela quantificação de perda mineral e profundidade da lesão por microrradiografia transversa. A conclusão foi que as lesões se mostraram mais suaves em menores temperaturas e menores tempos de exposição. Quanto ao tipo de esmalte, observaram que as lesões progrediram duas vezes mais rápido em esmalte bovino que em humano, ambos permanentes e evoluíram uma vez e meia mais rapidamente no esmalte humano decíduo que no permanente.

SATO et al. ${ }^{76}$ (1999) estudaram a morfologia do esmalte do incisivo bovino de um total de 14 espécies de Bovidae, por meio da microscopia eletrônica de varredura. Houve variação da ultra-estrutura de uma espécie para a outra. Comparando os incisivos bovinos decíduos com os permanentes, estes apresentaram prismas radiais enquanto naqueles os prismas eram tangenciais ou mistos de tangenciais e radiais. Ainda observaram que os decíduos se mostraram mais frágeis sob pressão que os permanentes.

\subsection{Desgaste dentário}

GRABENSTETTER et al. ${ }^{33}$ (1958) avaliaram a abrasão provocada em dentes humanos por dentifrícios usados em uma máquina de escovação, utilizando um teste de radiação dentária com nêutrons. Os resultados obtidos, em termos de quantidade de estrutura dentária perdida, mostraram 
que a taxa de esmalte abrasionado correspondeu a apenas 1 a $5 \%$ da quantidade de dentina perdida.

VRBIC; BRUDEVOLD; MCCANN ${ }^{88}$ (1967) determinaram o desgaste do esmalte após profilaxia com taça de borracha e pasta de pedra-pomes. Por meio da espectrofotometria do produto da profilaxia, determinaram a perda de estrutura dental como tendo variado entre 3 e $4 \mu \mathrm{m}$.

ZUNIGA; CALDWELL ${ }^{91}$ (1969) utilizaram, para mensuração de perda de estrutura do esmalte dental humano hígido e cariado, submetido a várias pastas profiláticas, um microdurômetro com penetrações do tipo KNOOP, sob uma carga de 500g. Foram realizadas três penetrações sobre a superfície a ser testada antes da profilaxia e três após ela. O tamanho da maior diagonal obtida após o tratamento profilático foi usado para o cálculo do desgaste. O desgaste do esmalte com lesões de mancha branca foi da ordem de $3,83 \mu \mathrm{m}$, sendo maior que o do esmalte hígido, que teve uma média de desgaste de 1,36 $\mu \mathrm{m}$.

DAVIS; WINTER ${ }^{24}$ (1976) testaram a abrasividade de vários dentifrícios e pastas profiláticas usadas na escovação realizada com uma máquina (10000 ciclos, pressão $200 \mathrm{~g}$ ), em esmalte humano. A avaliação foi feita pela perfilometria realizada antes e após a escovação. O desgaste provocado pelas pastas foi 20 vezes maior que o dos dentifrícios. Declararam que uma única sessão de profilaxia pode promover um desgaste maior que o de seis meses com escovação diária.

HEFFERREN ${ }^{35}$ (1976), baseado em itens estabelecidos pelo Comitê de Abrasão Laboratorial do Programa de Dentifrícios da Associação Dentária Americana (ADA), descreveu o método específico de medir a abrasividade in vitro de dentifrícios. Segundo ele, o método baseado na perda de peso não é recomendado para tecidos dentários porque a variação do conteúdo de água desses tecidos afeta seriamente a medida da perda de peso pela abrasão. Descartou o uso do perfilômetro porque os aparelhos são delicados e caros.

STOOKEY $^{80}$ (1978) utilizou o processo de determinação pela absorção atômica do cálcio liberado no produto pastoso da profilaxia com taça de borracha e pedra-pomes, realizada em incisivos humanos. Os 
resultados mostraram que em conseqüência da profilaxia a profundidade da abrasão foi de $1,57 \mu \mathrm{m}$ em dentina e de $0,08 \mu \mathrm{m}$ em esmalte, portanto, que 0 esmalte é 19,9 vezes mais resistente que a dentina.

WILLMANN; NORLING; JOHNSON ${ }^{85}$ (1980) submeteram dentes humanos extraídos, com manchas extrínsecas, a três tipos de procedimento de profilaxia: GI - jato de bicarbonato de sódio; GII - taça de borracha e pasta profilática; GIII - com instrumento de ultra-som. Para verificar a eficácia dos métodos na remoção das manchas e determinar seus efeitos na superfície do esmalte, foram utilizados os métodos da microscopia eletrônica de varredura e da perfilometria. $\mathrm{O}$ jato de bicarbonato removeu a maior parte das manchas. O perfilômetro mostrou um incremento da rugosidade antes e após o tratamento da seguinte ordem: GI 0,065/0,1810; GII 0,069/0,255; GIII $0,057 / 0,896$.

ATKINSON; COBB; KILLOY ${ }^{11}$ (1984) mediram o desgaste resultante da aplicação do jato de bicarbonato de sódio, em superfícies radiculares de dentes humanos extraídos. As avaliações foram feitas no microscópio ótico com foco graduado, microscópio eletrônico de varredura e exame histológico de um dente em microscópio ótico. O jato de bicarbonato de sódio removeu uma média de 636,6 $\mathrm{m}$ e a superfície resultante mostrou grande desgaste regular, bem delineado com total ausência de cemento e com exposição dentinária.

BOYDE $^{16}$ (1984) não encontrou nenhum tipo de desgaste em esmalte dental hígido, de dente humano, como efeito do jato de bicarbonato de sódio aplicado por 30 segundos, tempo considerado excessivo em clínica. Já, no esmalte com lesões de mancha branca e imaturo, houve um desgaste significativo. O método de análise foi a microscopia eletrônica de varredura.

PETERSSON et al. ${ }^{69}$ (1985) realizaram tratamentos com jato de bicarbonato de sódio, durante 30 segundos a uma distância de $5 \mathrm{~mm}$, em superfícies radiculares de pré-molares humanos extraídos. O experimento foi feito de três maneiras diferentes, quanto às áreas expostas aos tratamentos. A abrasão resultante foi analisada por microscopia eletrônica de varredura e por um rugosímetro. O jato de bicarbonato de sódio removeu o cemento 
radicular, expondo a dentina por meio de um desgaste de aproximadamente $25 \mu \mathrm{m}$.

NEWMAN; SILVERWOOD; DOLBY ${ }^{61}$ (1985) realizaram uma profilaxia com jato de bicarbonato de sódio em 30 dentes. O tratamento foi realizado por um tempo variando de dez segundos a cinco minutos e a uma distância de $5 \mathrm{~mm}$, com um ângulo de $60^{\circ}$ a $80^{\circ}$. Um grupo recebeu a profilaxia na junção amelodentinária e o outro apenas na coroa. Em metade de cada grupo o jato foi aplicado em um ponto fixo e na outra metade em movimento por uma área de 2,5mm x 5mm. Pela análise da superfície dentária por microscopia eletrônica de varredura observaram, mesmo quando a exposição ao jato foi pequena, grande perda de dentina e de cemento e mínimas mudanças no esmalte.

GALLOWAY; PASHLEY ${ }^{31}$ (1987) determinaram, através da pesagem, a perda de estrutura de esmalte, dentina e cemento, oriunda da profilaxia com jato de bicarbonato de sódio. O estudo foi feito com molares humanos e o jato foi aplicado por 5, 10, 15, 20, 30, 40 e 60 segundos. Com o menor tempo testado já houve grande perda de dentina e cemento, que foi aumentando com exposições maiores. Nenhuma perda de esmalte ocorreu, mesmo com 60 segundos de aplicação do jato.

CHRISTENSEN; BANGERTER ${ }^{20}$ (1987) avaliaram a perda de estrutura de esmalte e de dentina, em incisivos humanos, resultante da profilaxia com taça de borracha e várias pastas profiláticas. A análise do fosfato feita por meio da proporção de fosfato no conteúdo mineral de ambos os substratos ( $17 \%$ em esmalte e $12 \%$ em dentina) mostrou que, das pastas, a pedra-pomes foi a mais abrasiva e que o desgaste em dentina foi aproximadamente 70 vezes maior do que em esmalte $\left(34,42 \mu \mathrm{m} / \mathrm{mm}^{2}\right.$ e $0,4 \mu \mathrm{m} / \mathrm{mm}^{2}$ respectivamente). A medição estereoscópica pela microscopia eletrônica de varredura não conseguiu detectar o desgaste do esmalte, mas confirmou que a pasta de pedra-pomes foi a mais abrasiva.

BARBAKOW; LUTZ; IMFELD ${ }^{14}$ (1987) afirmaram, com base em uma revisão de literatura, que a marcação radioativa e a perfilometria são os métodos mais usados para avaliar o desgaste dentário resultante dos 
dentifrícios e pastas profiláticas. Acrescentaram que a avaliação também pode ser feita pela perda de massa. Ainda consideraram a qualidade das cerdas da escova de Robinson e a pressão aplicada no procedimento como sendo fatores relacionados à perda de estrutura dentária.

HOSOYA; JOHNSTON ${ }^{42}$ (1989) analisaram, junto a um microscópio eletrônico de varredura, o efeito sobre dentes decíduos de diversos sistemas de profilaxia. Concluíram que o jato de bicarbonato de sódio mostrou-se mais efetivo na limpeza das superfícies, principalmente quando usado por um minuto, apesar de produzir lesões de abrasão após 30 segundos. A pasta de pedra-pomes abrasionou muito a superfície do esmalte decíduo e os autores contra-indicaram seu uso em clínica.

GERBO et al. ${ }^{32}$ (1993) utilizaram dentes bovinos tratados com jato de bicarbonato de sódio e com taça de borracha e pedra-pomes para quantificar a diferença de rugosidade antes e após a profilaxia. Os tratamentos foram realizados em 30 segundos, que no dizer dos autores equivalem a 15 anos de acompanhamento odontológico trimestrais. O jato foi aplicado à distância de 4 a $5 \mathrm{~mm}$ e com angulação de $60^{\circ}$. A análise foi feita por perfilômetro e por microscópio de varredura. Os resultados não mostraram diferença significante na rugosidade antes e após a profilaxia, com ambos os tratamentos.

MARTA $^{55}$ (1997) avaliou o efeito do jato de bicarbonato de sódio em dentes permanentes jovens. A análise quantitativa das rugosidades da superfície do esmalte foi feita por um programa de computador que, após captar as imagens provindas de um microscópio ótico mede as sombras e penumbras sobre o espécime. Também foi realizada a análise qualitativa com microscópio eletrônico de varredura. Não houve diferença estatisticamente significante entre a rugosidade dos dentes antes e após a profilaxia.

AGGER; HORSTED-BINDSLEV; HOUGAARD ${ }^{1}$ (2001) trataram 50 dentes humanos extraídos com jato de bicarbonato de sódio, durante cinco segundos, à distância de 4,0mm e angulação de $90^{\circ}$, para avaliar a abrasividade nas superfícies radiculares. A análise foi feita pela microscopia 
eletrônica de varredura, que mostrou defeitos circulares de aproximadamente $5 \mathrm{~mm}$ de diâmetro e também por um perfilômetro que acusou um desgaste médio de $161 \mu \mathrm{m}$.

LUTZ; IMFELD ${ }^{53}$ (2002) utilizaram espécimes de esmalte e de dentina de dentes humanos para quantificar a abrasão provocada pela profilaxia com taça de borracha e escova de Robinson e várias pastas. Também avaliaram a eficácia na limpeza e o poder de polimento dos procedimentos. A análise da abrasão foi realizada pela contagem radioativa do material desgastado. Os resultados mostraram que a pasta de pedrapomes promoveu um desgaste excessivo, tanto em esmalte como em dentina, e gerou uma superfície muito rugosa, apesar de proporcionar boa limpeza. O desgaste em superfície de esmalte com escova de Robinson e taça de borracha foi praticamente idêntico, quando avaliado, com o auxílio de um rugosímetro, pelo aumento da rugosidade aritmética após a profilaxia.

HONÓRIO ${ }^{40}$ (2003) realizou análises quantitativa (com rugosímetro) e qualitativa (com microscopia eletrônica de varredura) do desgaste resultante de profilaxia com jato de bicarbonato de sódio e com escova de Robinson e pedra-pomes, sobre o esmalte bovino hígido e desmineralizado. Para confirmar a efetividade do processo de desmineralização empregado, foram realizados ensaios de microdureza que revelaram uma dureza inicial de 394 $\mathrm{KHN}$ e final de $241 \mathrm{KHN}$. O desgaste no esmalte hígido foi de 0,42 $\mu \mathrm{m}$ após

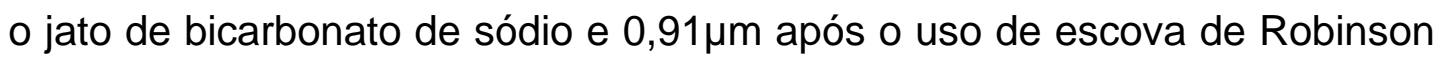
com pedra pomes e no esmalte desmineralizado foi de $0,94 \mu \mathrm{m}$ após o jato e de 1,60 $\mu \mathrm{m}$ após o tratamento com a escova. O esmalte desmineralizado desgastou-se mais que o hígido e a escova de Robinson desgastou mais o esmalte que o jato de bicarbonato de sódio.

\subsection{Testes de microdureza do esmalte dentário}

Desde o início do século passado, vários métodos baseados no princípio de resistência ao risco foram utilizados por vários pesquisadores 
como PICKERILL ${ }^{71}$ (1912), KARLSTRÖM ${ }^{44}$ (1927), HODGE; MCKAY 37 (1933), para medir a dureza do esmalte dentário.

HODGE $^{36}$ (1936) constatou uma grande diversidade nos resultados encontrados nos valores de microdureza de uma mesma estrutura dentária, quando avaliada em aparelhos diferentes como esclerômetro, microcaracter, pêndulo de Herbert, aparelho de Monotron, equipamento Brinell e Rockwell e pela dureza VICKERS. Concluiu que os testes de dureza por resistência à penetração eram inadequados para medidas em substâncias friáveis, pois os instrumentos causavam uma distorção destrutiva nos materiais friáveis.

KNOOP; PETERS; EMERSON ${ }^{47}$ (1939) desenvolveram a ponta de penetração KNOOP, que superou os inconvenientes dos instrumentos usados até então nos testes de dureza. Essa ponta era de diamante piramidal, firmemente montada em um suporte metálico, com ângulo longitudinal de $172,5^{\circ}$ e transversal de $130^{\circ}$ e podia ser pressionada contra um material com cargas de 1 a 500 gramas. As impressões resultantes tinham um formato de um losango, com a diagonal longa sete vezes maior que a curta e 30 vezes maior que a profundidade. O número de dureza KNOOP (KHN) é expresso em $\mathrm{Kg} / \mathrm{mm}^{2}$ e é a carga necessária para que o penetrador possa ocupar $1 \mathrm{~mm}^{2}$ da superfície a ser testada.

SOUDER; SCHOONOVER ${ }^{79}$ (1943) utilizaram a microdureza KNNOP para estudar o efeito de dentifrícios e soluções contendo açúcar e ácidos em esmalte e dentina. Dentre os resultados, encontraram valores de dureza de 250 KHN em lesões de mancha branca e de 350 KHN no esmalte hígido adjacente.

PHILLIPS; SWARTZ ${ }^{70}$ (1948) empregaram a microdureza KNOOP no estudo de efeito de aplicações tópicas de flúor em superfície de esmalte polido de dentes humanos. Constataram um aumento na dureza superficial do esmalte de 5,1\% com a solução de fluoreto de sódio e de 7,1\% com a de fluoreto estanhoso e ressaltaram as vantagens da utilização do penetrador KNOOP, na avaliação da dureza dentária.

CALDWELL et al. $^{18}$ (1957) analisaram a dureza de esmalte de dentes humanos íntegros e sem desgaste com um penetrador KNOOP com carga 
de 500g/10s com pelo menos dez impressões em cada fragmento de esmalte. A dureza média variou de 250 a 500 KNOOP. A variação foi atribuída à curvatura da superfície de esmalte e dizem que seria menor em esmalte plano e polido. Consideraram que não são grandes as variações de dureza entre dentes permanentes, decíduos irrompidos ou não, de indivíduos de idades diferentes, entre tipos de dentes de uma mesma boca e diferentes superfícies do mesmo dente.

CALDWELL et al. ${ }^{19}$ (1958) mediram a microdureza antes e após a desmineralização de dentes humanos, usando o penetrador KNOOP com dez impressões. A dureza foi maior no esmalte hígido sem ser polido (367 $\mathrm{KHN}$ ) do que no que recebeu polimento (325 KHN) e que a redução de dureza, por hora, com a desmineralização foi de $3,4 \%$ e $4,9 \%$ respectivamente.

CRAIG; PEYTON ${ }^{22}$ (1958) realizaram cortes transversais com 1 a $2 \mathrm{~mm}$ de espessura em dentes humanos íntegros para avaliar a microdureza com o penetrador KNOOP. A carga aplicada foi de $50 \mathrm{~g} / 15 \mathrm{~s}$ e os valores médios encontrados foram de $343 \mathrm{KHN}$ com variações de 272 a $440 \mathrm{KHN}$. Observaram diferenças acentuadas em diferentes cortes de um mesmo dente e de um local para outro em um mesmo corte e pequenas variações entre a dureza de dentes diferentes.

NEWBRUN; TIMBERLAKE; PIGMAN $^{60}$ (1959) realizaram um experimento com dentes humanos intactos e polidos e com dentes bovinos intactos em que mediram a microdureza inicial e após a exposição dos dentes a um tampão lactato com pH 5,0. A avaliação foi feita através de dez impressões com penetrador KNOOP, com carga de 500g/10s. A dureza média inicial dos dentes humanos foi de $367 \mathrm{KHN}$ e dos dentes bovinos foi de $356 \mathrm{KHN}$. A taxa de amolecimento foi ligeiramente maior para os dentes bovinos. Os dentes polidos apresentaram um menor desvio padrão entre as leituras individuais de microdureza, mas a queda na dureza foi mais rápida do que nas superfícies intactas. Os autores não observaram correlação entre a taxa de amolecimento e a dureza inicial. 
NEWBRUN; PIGMAN ${ }^{59}$ (1960) fizeram uma revisão dos métodos até então existentes para determinação da dureza superficial do esmalte e da dentina. Enalteceram o penetrado KNOOP, apontando suas vantagens como realizar impressões com dimensões bem definidas e reproduzíveis, não produzir distorções e não danificar a estrutura. Concluíram, em relação à dureza do esmalte o seguinte: está entre 300 e $400 \mathrm{KHN}$, não sofre interferência da idade, do sexo e nem do tipo de dente e lado da boca; que a susceptibilidade à cárie independe dela; suas alterações são apropriadas para acompanhar o progresso de lesões de carie natural e artificial.

FEAGIN; KOULOURIDES; PIGMAN ${ }^{26}$ (1969) avaliaram a relação entre a perda ou ganho de dureza do esmalte e desmineralização e remineralização. Foram utilizadas superfícies planas de esmalte humano e bovino, nas quais foram feitas cinco impressões antes e cinco após os procedimentos de des-remineralização, com distância de $60 \mu \mathrm{m}$ entre as cinco primeiras e as últimas cinco. A concentração de cálcio e fosfato nas soluções des e remineralizantes foi determinada após os tratamentos dos espécimes. A diminuição e o aumento na dureza KHN apresentaram uma relação linear com a perda ou ganho de cálcio e fosfato pelo esmalte. Portanto, concluíram que as medidas de dureza do dente podem ser usadas como indicadoras de seu grau de desmineralização.

DAVIDSON; HOEKSTRA; ARENDS $^{23}$ (1974) realizaram uma investigação, com incisivos e pré-molares humanos e incisivos bovinos, para correlacionar a microdureza KNOOP com a diminuição do conteúdo de cálcio após condicionamento ácido e uma desmineralização lenta. O conteúdo de cálcio foi determinado por um microscópio eletrônico de varredura com um espectrômetro de raios-X acoplado. A microdureza e o conteúdo de cálcio foram menores onde houve a penetração do ácido do que nas áreas não afetadas. Na lesão formada pela desmineralização lenta a microdureza foi 50\% menor do que no esmalte hígido. A microdureza do esmalte condicionado foi seis vezes maior que o do com lesão de cárie artificial. Não houve diferença entre o esmalte humano e bovino. 
PURDELL-LEWIS; GROENEVELD; ARENDS $^{73}$ (1976) avaliaram a microdureza superficial e longitudinal em esmalte humano hígido e com lesões de cárie artificial. Observaram uma grande variação de microdureza entre diferentes dentes e áreas de um mesmo dente. Os valores de dureza a uma mesma distância da superfície, mas em diferentes áreas de uma mesma lesão, foram semelhantes. A diminuição da microdureza e desmineralização estava diretamente relacionada à dureza inicial do esmalte.

ARENDS; SCHUTHOF; JONGEBLOED ${ }^{7}$ (1979) testaram a microdureza KNOOP de 60 dentes bovinos e 50 dentes humanos desgastados e polidos, após a formação de lesões de cárie artificial. Foram aplicadas cargas de 25, 50, 100, 200 e 500g por dez segundos. A dureza KNOOP do esmalte humano foi de $317 \pm 30$ e a do esmalte bovino foi ligeiramente menor. De acordo com o estudo, quando o comprimento da impressão é medido em função da raiz quadrada da carga, encontra-se uma relação linear entre o esmalte humano e bovino hígidos assim como para o esmalte com lesões artificiais de cárie. Nem a camada superficial da lesão, nem o esmalte sadio subjacente influenciam as impressões. Com isso, provaram que as medidas das impressões refletem o grau de descalcificação da lesão.

FEATHERSTONE et al. ${ }^{27}$ (1983), fizeram uma comparação direta entre os métodos de avaliação da microrradiografia quantitativa e perfis de microdureza (dureza KNOOP) em cárie artificial de esmalte de sete dentes humanos e concluíram que as duas técnicas podem ser usadas. Os resultados mostraram uma relação linear entre o percentual de mineral determinado pela microrradiografia e a raiz quadrada do número de dureza KNOOP obtido, no intervalo de 40-90\% de mineral em volume.

WHITE $^{84}$ (1987) para avaliar a capacidade de remineralização de dentifrícios contendo flúor sobre o esmalte desmineralizado usou os métodos de microdureza superficial e microrradiografia, estabelecendo uma comparação entre eles. Considerou que existe uma relação linear da diagonal de impressão com o conteúdo mineral da superfície do esmalte 
para lesões de cárie de pequena profundidade (menos de 50 $\mu \mathrm{m}$ ). Em lesões subsuperficiais profundas recomendou que a microdureza superficial fosse substituída pela microrradiografia ou pela microdureza longitudinal.

ZERO et al. $^{90}$ (1990) realizaram uma pesquisa para verificar se os testes de permeabilidade ao iodo e a microdureza superficial poderiam ser utilizados como métodos de avaliação indireta das alterações iniciais do esmalte devido a desmineralização no processo de cárie. O estudo foi feito com esmalte bovino. A análise de cálcio e fosfato na solução foi feita pela absorção atômica e o teste de dureza superficial foi realizado com penetrador KNOOP, com carga de 50 gramas. O teste de permeabilidade ao iodo foi realizado usando $5 \mu \mathrm{L}$ de $\mathrm{KI}(2 \mathrm{~mol} / \mathrm{L})$ por três minutos. Os resultados mostraram que as alterações na permeabilidade ao iodo e a microdureza superficial aumentaram linearmente com o tempo de dissolução e foram similares à perda mineral, concluindo que ambos os métodos se prestam para avaliação da dissolução do esmalte em estádios iniciais.

ATTIN et al. ${ }^{9}$ (1997) fizeram uma pesquisa com 60 espécimes de esmalte bovino para comparar a microdureza de diferentes superfícies de esmalte erosionado por refrigerante e o desgaste causado pela escovação. A microdureza obtida foi a dureza VICKERS e o desgaste após a abrasão e a erosão foi obtido com a perfilometria. Quanto maior o tempo de imersão do esmalte no refrigerante, maior foi o desgaste e menor a microdureza. A conclusão a que os autores chegaram foi de que a susceptibilidade do esmalte erosionado à abrasão pela escovação está relacionada com a microdureza.

KIELBASSA et al. ${ }^{45}$ (1999), para avaliar o efeito da radiação na microdureza da dentina, utilizaram blocos de incisivos bovinos submetidos a quatro tratamentos: I - sem irradiação; II - com irradiação maior que 60 Gy; III - sem irradiação com fluoretação diária; IV - com irradiação e fluoretação diária. Para os testes de microdureza, utilizaram um penetrador KNOOP com carga de $50 \mathrm{~g} / 30$ s e encontraram no grupo controle o valor de 62,63 KHN e após a irradiação 8,74 KHN. Nos fluoretados a microdureza foi de 11,19 KHN nos sem irradiação e 10,03 KHN no grupo irradiado. A conclusão foi 
que a radiação afeta muito a dentina e que, a fluoretação tópica diminui a sua microdureza e não previne os efeitos da radiação, quando a saliva não está presente.

KIELBASSA et al. ${ }^{46}$ (1999) realizaram um estudo in situ, no qual espécimes de esmalte humano, irradiados com 60 Gy e não irradiados, foram escovados diariamente com dentifrício sem flúor por seis semanas e, durante as refeições, ficavam armazenados em uma solução de sacarose a $10 \%$. Por meio de microrradiografia transversal e de testes de dureza KNOOP (5g/30s) observaram que não houve diferença entre os esmaltes não irradiados e irradiados e concluíram que estes não são mais suscetíveis à cárie, se uma técnica de higiene bucal adequada for implementada. Também afirmaram que a microdureza é uma medida direta do conteúdo mineral, podendo ser utilizada em estudos de des-remineralização.

HOSOYA et al. ${ }^{41}$ (2000) avaliaram a microdureza (KNOOP 15g/15s) da dentina de dentes decíduos com cárie proximal. As medidas foram feitas nas regiões de dentina sem cárie; na dentina adjacente à cárie; na dentina não relacionada à cárie. A microdureza diminuiu da junção amelodentinária em direção à polpa, sob a cárie foi menor que nas outras regiões e sempre na dentina cariada foi menor que na dentina sem cárie.

LUSSI et al. ${ }^{52}$ (2000) avaliaram o poder erosivo de um refrigerante (Sprite ${ }^{\circledR}$ ) e de iogurte em 60 dentes decíduos e 60 permanentes humanos que ficaram imersos nos produtos por três minutos. Mediram a microdureza superficial (dureza KNOOP 50g) e constataram que os valores iniciais (sem ação do refrigerante) foram menores nos dentes decíduos em relação aos permanentes. Com a imersão em Sprite ${ }^{\circledR}$ a microdureza diminuiu mais do que em iogurte e os decíduos não foram mais suscetíveis à erosão que os permanentes.

FREITAS et al. $^{30}$ (2004) avaliaram o efeito de diferentes agentes clareadores na microdureza da dentina de molares humanos. O tratamento consistiu de uma aplicação diária do agente na dentina por oito horas, imersão em saliva artificial por 16 horas, durante 42 dias. Após isso, os espécimes ficaram imersos em saliva por 14 dias. A microdureza (KNOOP 
$10 \mathrm{~g} / 5 \mathrm{~s}$ ) foi medida no início, 8 horas e 7, 14, 21, 28, 35 e 42 dias de tratamento e 7 e 14 dias após o tratamento. Alguns agentes não alteraram a microdureza: NiteWhite Excel 2 Z 10\% e 22\% e Opalescence 20\%. Os agentes Rembrant $10 \%$ e $22 \%$ e Opalescence $10 \%$ reduziram a microdureza depois de 14 dias. Após o tratamento, todos os agentes promoveram um aumento de microdureza. Concluíram que durante o tratamento alguns agentes levam a uma diminuição transitória da microdureza da dentina. No pós-tratamento, a saliva artificial teve efeito remineralizador.

\subsection{Remineralização dentária pela saliva}

A comunidade científica passou a pesquisar a participação da saliva no processo de remineralização do esmalte depois que HEAD $^{34}$ (1912) observou que uma mancha branca de descalcificação, produzida artificialmente, desaparecia após a imersão em saliva.

JOHANSSON $^{43}$ (1965), após promover a desmineralização de fragmentos de dentes humanos por períodos de dois a sete dias, imergiu-os em saliva natural ou sintética, por uma semana. A ocorrência de remineralização foi observada por microscopia de luz polarizada, microrradiografias e por alterações na permeabilidade do esmalte a corantes. O processo de remineralização ocorreu rapidamente nas primeiras 24 horas, reduziu a intensidade até 48 horas, e não houve incremento na deposição de mineral com a imersão dos fragmentos em saliva por um período adicional de três semanas. O autor atribuiu essa paralisação no processo ao bloqueio de difusão iônica para o interior do esmalte devido à deposição mineral em sua camada mais externa.

LENZ $^{51}$ (1967) definiu a remineralização como sendo o processo que ocorre quando o esmalte desmineralizado é exposto à saliva supersaturada (em relação aos conteúdos de fosfatos e cálcio) e sofre uma nova mineralização em ordem inversa ao que se perdeu nos momentos de dissolução da estrutura. A restituição da integridade do tecido acontece 
porque os espaços intercristais abertos anteriormente se fecham, devido a uma nova formação de cristais (in vivo) ou pela precipitação de componentes salivares (in vitro).

SILVERSTONE; POOLE ${ }^{78}$ (1969) estudaram dentes humanos com lesões de cárie incipientes cortados no centro da lesão, após imersão por quatro semanas em água, em solução remineralizadora contendo cálcio e em um "pool" de saliva não estimulada. A observação foi feita pela microscopia de luz polarizada, microrradiografias e microscopia eletrônica de varredura. As características microscópicas das lesões sofreram alterações após a exposição à saliva ou solução remineralizadora, com redução na porosidade do esmalte.

SILVERSTONE $^{77}$ (1977), com base em uma revisão da literatura, declarou que o cálcio, o fosfato e outros íons que se precipitam sobre o esmalte para remineralizá-lo se originam da dissolução inicial do tecido, de fontes externas ou de combinação de ambos. Diz que inúmeros estudos demonstraram, em laboratório, que a superfície do esmalte remineraliza-se rapidamente, quando a saliva ou soluções remineralizadoras artificiais com alta concentração de cálcio são utilizadas.

ÖGAARD; TEN BOSCH ${ }^{66}$ (1994) em um trabalho in vivo no qual houve regressão de manchas brancas que haviam sido produzidas em 14 pré-molares, por meio de bandagem dos dentes, durante quatro semanas, evidenciaram a importância da saliva no processo de remineralização. As avaliações foram feitas por meio de um coeficiente ótico na área bandada antes da bandagem e uma semana após a remoção das bandas. Concluíram que a regressão das lesões de cáries iniciais, na presença de saliva, é um processo relativamente rápido.

AMAECHI; HIGHAM; EDGAR $^{5}$ (1999) trabalhando com incisivos bovinos, avaliaram a influencia da saliva no grau de erosão in vitro. Cada dente foi seccionado em três porções e em cada uma delas produziu-se erosão por ciclagem entre suco de laranja e saliva artificial (A), ou água (B), ou por simples imersão em suco de laranja (C), durante um período de 12 horas. A perda mineral foi quantificada por microrradiografia transversa. A 
perda mineral foi menor no grupo A, de forma significante, comparativamente aos outros dois grupos. Como conclusão, afirmaram que a saliva artificial reduziu o grau de erosão e remineralizou as lesões da mesma forma que ocorre in vivo.

ATTIN et al. ${ }^{10}$ (2000) realizaram uma pesquisa em que 84 corpos de prova de esmalte de incisivos bovinos, polidos, foram submetidos a dez diferentes ciclos de des-remineralização. A desmineralização ocorreu pela imersão dos espécimes no refrigerante Sprite Light ${ }^{\circledR}$ por um minuto e a remineralização pela imersão dos espécimes em saliva artificial por 0,10, 60 e 240 minutos. Após a remineralização, os espécimes eram escovados em uma máquina automática e a perda de esmalte era avaliada pela perfilometria. Chegaram à conclusão de que a resistência do esmalte erosionado à abrasão provocada pela escovação, foi tanto maior quanto maior foi o tempo em que o esmalte se submeteu à remineralização.

AMAECHI; HIGHAM ${ }^{2}$ (2001) avaliaram, in vitro, a capacidade da saliva na remineralização de lesões iniciais de erosão, produzidas em esmalte bovino, pela imersão em suco de laranja durante uma hora. Divididos em quatro, os espécimes foram colocados, por 28 dias em agentes remineralizantes, com igual $\mathrm{pH}$ de 7,2 e, 0,002 ppm de flúor: GI controle; GII saliva natural; GIII saliva artificial; GIV solução remineralizadora. Por meio de microrradiografias realizadas após a remineralização, constataram que houve um ganho significativo de minerais em todos os grupos experimentais, sendo maior para o GIV e menor para o GIII. Como conclusão, afirmaram que os três agentes remineralizadores foram efetivos no esmalte recémerosionado.

AMAECHI; HIGHAM ${ }^{3}$ (2001) produziram erosões em esmalte de prémolares humanos, com suco de laranja e colaram os espécimes na face palatina e lingual de incisivos laterais, superior direito e inferior esquerdo, de dez voluntários. Estes mascavam chicletes, sem açúcar, quatro vezes ao dia. Após 28 dias, a perda mineral e a profundidade de erosão no esmalte foram avaliadas por microrradiografias. Como conclusão, afirmaram que a saliva pode remineralizar o esmalte recém-erosionado e que o grau de 
remineralização varia com a localização intrabucal, o que explica a diferença de susceptibilidade à erosão da maxila e da mandíbula.

MARTA $^{56}$ (2002) realizou um trabalho em que dez voluntários usaram dispositivos intrabucais palatinos, contendo dois blocos de esmalte bovino (4×4×2mm) desmineralizados artificialmente, durante períodos cruzados de dez dias, com descanso de sete dias entre eles. Foram usados 80 blocos de esmalte e estabelecidos quatro grupos, sendo que os grupos III e IV receberam uma profilaxia com jato de bicarbonato de sódio antes da instalação do dispositivo, e todos eles realizavam quatro escovações por dia, após as refeições, com dentifrício da seguinte forma: GI - sem flúor; GII fluoretado (1500 ppm MFP); GIII - sem flúor e GIV fluoretado (1500 ppm MPF). Realizando medidas de microdureza superficial, com penetrador KNOOP e carga de $50 \mathrm{~g} / 7 \mathrm{~s}$, no esmalte hígido, desmineralizado e tratado, concluiu que a remoção total da placa bacteriana não influiu na remineralização observada nos grupos que utilizaram o dentifrício fluoretado mas, na ausência de flúor, a profilaxia foi significativa para o processo de remineralização.

NUNES $^{62}$ (2002) avaliou o efeito remineralizador da saliva artificial, associado ou não a dois dentifrícios contendo flúor, em esmalte bovino desmineralizado. Os espécimes, divididos em cinco grupos, foram submetidos a períodos de desmineralização e remineralização a $37^{\circ} \mathrm{C}$, durante sete dias. Foram realizados quatro ciclos de desmineralização, entre os quais, três grupos foram imersos duas vezes por dia, em solução contendo dentifrício (placebo, com 550ppm e 1100ppm). Um grupo passou apenas pelo processo de desmineralização e o outro por processo de desremineralização. Por meio dos testes de microdureza KNOOP superficial, constatou-se que os grupos submetidos ao flúor tiveram desempenhos semelhantes em ambas as concentrações. Como conclusão inferiu que a saliva artificial desempenha efeito importante na remineralização do esmalte e que esse efeito é potencializado pelo flúor.

RIOS $^{75}$ (2004) realizou um trabalho com voluntários, que usaram um dispositivo intrabucal contendo 12 espécimes de esmalte, seis bovinos e seis 
humanos, por sete dias. Os aparelhos eram imersos em 150ml de refrigerante tipo cola, por cinco minutos, quatro vezes ao dia. Eram realizadas escovações com dentifrício fluoretado em alguns espécimes, logo após a imersão na bebida, em outros uma hora após a imersão no refrigerante e outros não foram escovados. Todos esses procedimentos se repetiram por outro período de sete dias, com a única diferença que após a imersão na saliva os voluntários mascavam um chiclete sem sacarose por 30 minutos. Foram realizados testes de microdureza KNOOP (com carga de $25 \mathrm{~g} / 5 \mathrm{~s}$, com cinco impressões em cada corpo de prova) bem como testes de desgaste com um rugosímetro. Houve perda de dureza, que foi maior no esmalte humano e desgaste que foi maior no bovino. O fluxo salivar, estimulado, promoveu um menor desgaste e uma menor perda de dureza. Foi mostrado que a estimulação salivar, após um ataque erosivo, diminui o desgaste dentário e que se a escovação for realizada uma hora após o contato com o refrigerante, a abrasão que se associa à erosão é menor do que quando a escovação é imediata.

FRAGA $^{29}$ (2005) tratou sessenta espécimes de esmalte bovino (4mm x 4mm), dos quais 30 desmineralizados, com jato de bicarbonato de sódio a uma distância de 5mm, por dez segundos, com uma angulação de $90^{\circ}$. Metade dos espécimes de esmalte hígido e metade dos desmineralizados foram imersos em $20 \mathrm{ml}$ de saliva artificial, a $37^{\circ} \mathrm{C}$, por quatro horas e as outras metades por 28 dias. A microdureza superficial do esmalte e 0 desgaste foram avaliados com um microdurômetro (dureza KNOOP, carga de $25 \mathrm{~g} / 5 \mathrm{~s}$, cinco impressões por bloco) e um rugosímetro, respectivamente. A profilaxia com jato de bicarbonato de sódio alterou a microdureza superficial do esmalte bovino hígido de 300,47 KHN para 298,16 KHN e do esmalte bovino desmineralizado de $193,47 \mathrm{KHN}$ para 272,47 KHN. O desgaste do esmalte bovino hígido, após o jato de bicarbonato de sódio, foi de $0,319 \mu \mathrm{m}$ e do desmineralizado foi de $0,719 \mu \mathrm{m}$. Conclui que a profilaxia com jato de bicarbonato de sódio não alterou significantemente a microdureza superficial do esmalte hígido, mas aumentou significantemente a do esmalte desmineralizado; em quatro horas a saliva não alterou 
significantemente a microdureza superficial do esmalte hígido e desmineralizado, porém alterou 0 desgaste do esmalte bovino desmineralizado; em 28 dias a saliva alterou significantemente a microdureza superficial e o desgaste do esmalte bovino hígido e desmineralizado. 
3 Proposição

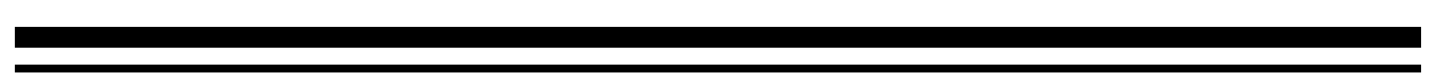




\section{Proposição}

O objetivo deste estudo foi avaliar in vitro se a aplicação do jato de bicarbonato de sódio no esmalte bovino promove desgaste e diminuição da sua microdureza superficial e qual é o efeito da saliva artificial, em diferentes tempos de ação, na reparação de possíveis alterações ocorridas. 


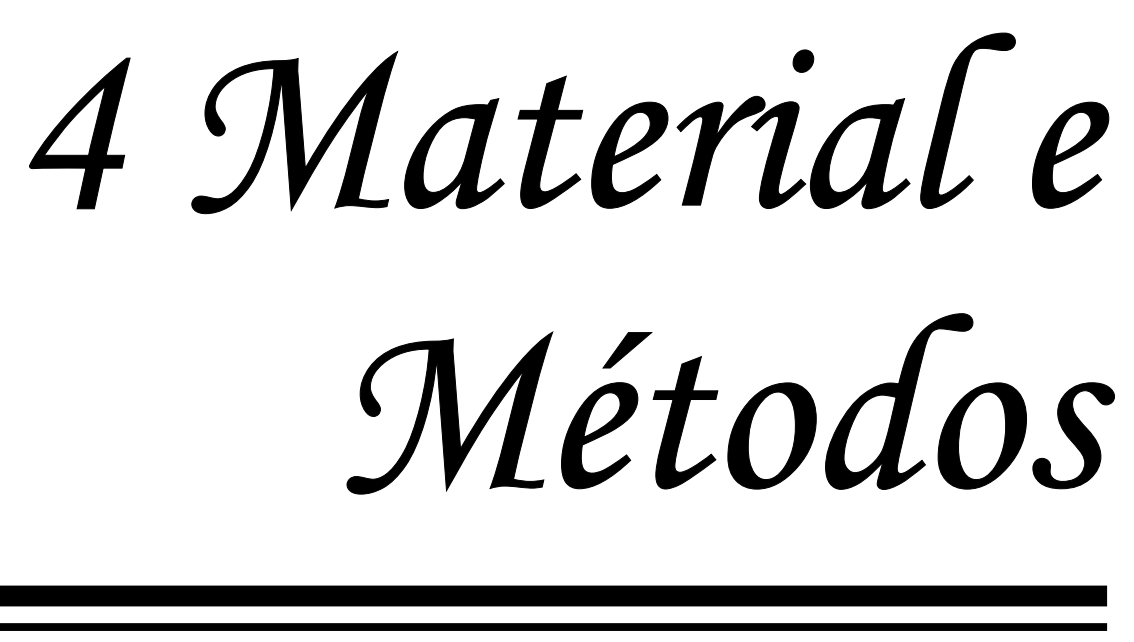




\section{Material e Métodos}

\subsection{Delineamento Experimental}

Este trabalho, realizado in vitro, avaliou a microdureza superficial e o desgaste associados à simulação da profilaxia profissional com jato de bicarbonato de sódio, em esmalte hígido de dentes bovinos, bem como avaliou o efeito da saliva artificial sobre as alterações ocorridas neste esmalte.

Todos os espécimes de esmalte bovino, num total de 15 , foram submetidos aos seguintes procedimentos, sucessivamente:

- $\quad$ medida da microdureza superficial inicial

- $\quad$ simulação da profilaxia com jato de bicarbonato de sódio

- $\quad$ medida da microdureza superficial

- medida do desgaste

- $\quad$ imersão em saliva artificial por uma hora

- $\quad$ medida da microdureza superficial

- medida do desgaste

- $\quad$ imersão em saliva artificial por 24 horas

- $\quad$ medida da microdureza superficial

- medida do desgaste

- $\quad$ imersão em saliva artificial por sete dias

- medida da microdureza superficial

- medida do desgaste

A FIGURA 1 ilustra o delineamento experimental. 


\subsection{Obtenção dos blocos de esmalte bovino}

Foram utilizados no presente trabalho dentes incisivos bovinos extraídos de gado da raça Nelore, com idade média de 36 meses, abatidos para consumo no Frigorífico Vangélio Mondelli Ltda., em Bauru, SP. Após a extração, os dentes permaneceram armazenados em recipientes de vidro contendo solução de timol, sob temperatura ambiente. Os incisivos foram limpos com curetas periodontais para remover todo e qualquer resíduo de tecido gengival aderido à superfície dentária.

Os dentes passaram por uma seleção prévia, eliminando aqueles com trincas, rachaduras, grande desgaste incisal e hipocalcificações visualizadas a olho nu. A seguir, foram removidas as raízes, com o auxílio de um torno de polimento odontológico adaptado para corte (Fábrica Nacional de Motores Monofásicos Nevoni / Série 16.223, Tipo: TG1/3, São Paulo, SP) e um disco diamantado Diaflex-F (Wilcos do Brasil, Indústria e Comércio Ltda., Petrópolis, RJ), sendo feita uma secção na porção cervical dos dentes. Para este corte não houve necessidade de fixação prévia do incisivo bovino, pelo seu tamanho, bastando que o elemento dentário fosse firmemente segurado pela porção coronal e pela raiz, sendo posteriormente levado manualmente de encontro ao disco adaptado na máquina de corte.

Em seguida, as coroas foram fixadas com godiva termoativada (Kerr Corporation, USA) em uma pequena placa de acrílico cristal (40mm X 40mm $X 5 \mathrm{~mm}$ ), para facilitar a adaptação na máquina de corte. A placa de acrílico foi acoplada a um aparelho de corte de precisão ISOMET Low Speed Saw (Bulher Ltda., Lake Bluff, IL, USA) (FIGURA 2) e com o auxílio de dois discos diamantados dupla face - XLI 2205, "high concentration", 102mm X 0,3mm X 12, 7mm (Extec Corp., Enfield, CT, USA / Ref: 12.205) e um espaçador de aço inoxidável $(7 \mathrm{~cm}$ de diâmetro, $4 \mathrm{~mm}$ de espessura e orifício central de $1,3 \mathrm{~cm}$ ) entre os discos com velocidade de300 rpm, refrigerado com água deionizada, foram obtidos os espécimes de esmalte de $4 \mathrm{~mm} \times 4 \mathrm{~mm}$ da porção mais plana da coroa, por meio de uma secção dupla no sentido 
cervicoincisal e outra no sentido mesiodistal (FIGURA 3). No total, foram obtidos 30 espécimes de esmalte bovino.

\subsection{Planificação e polimento do esmalte bovino}

Obtidos os blocos de esmalte, estes foram fixados com cera pegajosa em bastão (ASFER - Ind. Química Ltda.) com o auxílio de uma espátula Lecron (Duflex Ind. Bras.) e uma lamparina (JON, Ind. Bras.) no centro de um disco de acrílico cristal (30mm de diâmetro por $8 \mathrm{~mm}$ de espessura), com a maior área plana do esmalte voltada para o disco, com o intuito de primeiramente realizar a planificação da dentina. O conjunto disco/dente foi adaptado em uma Politriz Metalográfica (APL 4, Arotec, Cotia, SP) (FIGURA 4) com sistema de polimento múltiplo capaz de realizar o polimento automático de seis corpos de prova, permitindo o paralelismo entre as superfícies polidas e a base de acrílico onde foram fixados os espécimes. Para a planificação foi utilizada uma lixa de silicone carbide de granulação 320 (Extec Corp.), com refrigeração à água deionizada, até que os blocos ficassem com espessura de aproximadamente $4 \mathrm{~mm}$. Para tanto, a politriz foi acionada em baixa velocidade, com dois pesos padrão de $86 \mathrm{~g}$, durante 30 segundos a sete minutos, até se alcançar a espessura desejada.

Em seguida, os blocos foram removidos do disco de acrílico e limpos com xilol (MERCK, Darmstadt- GERMANY) para remover todo resíduo de cera. Posteriormente, foram novamente fixados com cera no centro da placa de acrílico com o esmalte voltado para cima onde foi feito o desgaste e polimento para obtenção de uma superfície plana, paralela à base do acrílico e polida, indispensável para a realização dos testes de desgaste e microdureza superficial. Novamente, o conjunto foi adaptado na politriz e inicialmente o esmalte foi desgastado com uma lixa de silicone carbide de granulação 600 (Extec Corp.), com refrigeração à água deionizada, durante um minuto, com dois pesos padrão de $86 \mathrm{~g}$, em velocidade baixa. Em seguida, foi feito o polimento do esmalte com lixa de silicone carbide de 
granulação 1200 (Extec Corp.), com refrigeração à água deionizada, durante dois minutos e 30 segundos, com dois pesos padrão de $86 \mathrm{~g}$, em velocidade alta, após o qual pode-se observar uma superfície de aspecto vítreo. Para finalizar o polimento, foi utilizado um feltro (Extec Corp.) umedecido com uma suspensão de diamante de $1 \mu \mathrm{m}$ (Buehler), durante três minutos, com dois pesos, em velocidade alta. Este tratamento teve o objetivo de planificar e remover ranhuras do bloco de esmalte, para permitir a aferição do desgaste no local (FIGURA 5).

Para impedir que os grãos das primeiras lixas interferissem na qualidade do polimento das seguintes, entre cada etapa de polimento, o conjunto dente/disco foi levado a um aparelho de ultra-som Ultra Sonic Cleaner 750 (Unique Ind. e Com. de Produtos Eletrônicos Ltda., São Paulo, $\mathrm{SP}$ ), com freqüência de $25 \mathrm{KHz}$, durante dois minutos, com água deionizada. Ao final do polimento os blocos ficaram imersos por dez minutos em água deionizada corrente.

\subsection{Análise da microdureza superficial}

A microdureza superficial inicial do esmalte foi avaliada utilizando-se um microdurômetro (HMV-2000/ Shimadzu Corporation, Japan) acoplado a um microcomputador e um software específico para a análise das imagens (Cams-Win-New Age Industries/ USA) (FIGURA 6). Um penetrador diamantado piramidal tipo KNOOP foi utilizado (FIGURA 7), com carga estática de $25 \mathrm{~g}$, aplicada por cinco segundos. Em cada corpo de prova foram realizadas cinco impressões aleatoriamente, englobando diferentes áreas da superfície com mais de $100 \mu \mathrm{m}$ da lateral do bloco. As impressões foram realizadas na porção central dos fragmentos. Para medi-las, duas marcas pontilhadas que aparecem na tela do computador se sobrepõem aos vértices agudos do losango correspondente à impressão, determinando o comprimento da maior diagonal (FIGURA 8) e conseqüentemente os 
resultados da dureza KNOOP, através do cálculo automático feito pelo software da seguinte equação:

\section{$\mathrm{KHN}=\underline{\mathrm{C} . \mathrm{C}}$}

$$
\mathbf{d}^{2}
$$

Sendo: $\mathrm{KHN}=$ valor de dureza Knoop

C (constante) $=14,230$

$c=25$ gramas

$\mathrm{d}=$ comprimento da maior diagonal da impressão.

A média do comprimento da diagonal maior das cinco impressões foi utilizada para excluir os blocos com microdureza fora do padrão. Foram desprezados blocos com média de comprimento da impressão com valor $10 \%$ acima ou $10 \%$ abaixo da média de todos os blocos e aqueles com desvio-padrão do comprimento das impressões acima de $10 \%$ do valor de sua própria média. Dos 30 espécimes, 15 foram selecionados para a realização do experimento. Neste momento, os espécimes constituíram o grupo MI.

\subsection{Amostra}

Para o estudo relacionado à microdureza superficial do esmalte os espécimes constituíram cinco grupos, conforme a fase de tratamento em que se encontravam, a saber:

- $\quad$ Grupo MI - sem tratamento

- Grupo MII - tratamento com jato de bicarbonato de sódio

- Grupo MIII - tratamento com jato de bicarbonato de sódio e imersão em saliva artificial por uma hora

- Grupo MIV - tratamento com jato de bicarbonato de sódio e imersão em saliva artificial por 24 horas 
- Grupo MV - tratamento com jato de bicarbonato de sódio e imersão em saliva artificial por sete dias

Para o estudo relacionado ao desgaste do esmalte os espécimes constituíram quatro grupos, conforme a fase de tratamento em que se encontravam, a saber:

- $\quad$ Grupo DI - tratamento com jato de bicarbonato de sódio

- Grupo DII - tratamento com jato de bicarbonato de sódio e imersão em saliva artificial por uma hora

- Grupo DIII - tratamento com jato de bicarbonato de sódio e imersão em saliva artificial por 24 horas

- Grupo DIV - tratamento com jato de bicarbonato de sódio e imersão em saliva artificial por sete dias

\subsection{Tratamento com jato de bicarbonato de sódio}

Primeiramente, metade da superfície de cada espécime foi protegida com esmalte para unha vermelho (Colorama) para que apenas uma parte restrita do corpo de prova ficasse exposta à ação do agente profilático. Para tanto, foi colada uma tira de fita adesiva de um lado e no outro foi aplicado o esmalte para unha (FIGURA 9). A seguir, os corpos de prova foram posicionados em uma base plana, removida a tira adesiva e aplicado um jato de bicarbonato de sódio (Dabi Atlante Indústrias Médico Odontológicas LTDA) a uma distância de $5 \mathrm{~mm}$ do esmalte bovino, durante dez segundos, com uma angulação de $90^{\circ}$, sem interrupção. Após o procedimento de simulação da profilaxia, foi removida a película de esmalte para unha e os espécimes foram lavados em água deionizada para em seguida serem levados ao aparelho de ultra-som durante dez minutos, com o intuito de que todas as partículas oriundas da simulação da profilaxia fossem removidas. Neste momento, os espécimes constituíram o grupo MII e o grupo DI, sendo realizada a seguir a análise da microdureza superficial e do desgaste. 


\subsection{Análise da microdureza superficial após tratamento com jato de bicarbonato de sódio}

A microdureza superficial de cada espécime foi avaliada seguindo a metodologia descrita no item 4.4.

\subsection{Avaliação do desgaste}

O perfil da superfície de esmalte foi avaliado a partir de um Rugosímetro Hommel Tester T 1000 (Hommelwerke, Gmbh, Alte Tuttinger Strebe 20 D-7730 VS-Schwenningen) (FIGURA 10), que dispõe de uma ponta apalpadora esférica (FIGURA 11) que percorre a superfície e é acoplado a uma unidade que tem como função processar e interagir as informações quantitativamente.O resultado é registrado de imediato, digitalmente em um visor de cristal líquido. Para este estudo o rugosímetro foi conectado a um microcomputador que processava e armazenava todas as informações pertinentes aos ensaios. Com o auxílio de um software do equipamento (Turbo Datawin-NT Version 1.34, Copyright (C 2001) além dos dados específicos de rugosidade, foram obtidos também os perfis das superfícies testadas, sendo estes importantes para a ilustração e quantificação do desgaste. O perfil traçado pelo rugosímetro percorreu a superfície dos corpos de prova passando por áreas de esmalte tratado e não tratado e como o esmalte polido não tratado se assemelhava muito a uma linha reta, tornou-se fácil a identificação da região submetida à simulação da profilaxia. Assim sendo, a perda de estrutura dentária foi quantificada pelo perfil medindo-se a distância em micrometros da linha média do gráfico, correspondente à linha do plano do espécime, até o maior vale correspondente à área desgastada (FIGURA 12). Com o objetivo de aferir a 
quantidade de desgaste mais próxima da realidade, em cada bloco a medida foi realizada em cinco áreas distintas e obtida a média.

\subsection{Tratamento pela saliva artificial}

A saliva artificial utilizada foi manipulada na Pharmácia Specífica Ltda, Bauru, SP, com a composição de:

- cloreto de sódio. $.0,674 \mathrm{~g}$

- cloreto de potássio $0,960 \mathrm{~g}$

- cloreto de magnésio hexahidratado. $0,041 \mathrm{~g}$

- cloreto de cálciodihidartado $0,274 \mathrm{~g}$

- metilparabeno $1,500 \mathrm{~g}$

- propilparabeno $0,200 \mathrm{~g}$

- carboximetilcelulose $10,0 \mathrm{~g}$

- sacarina $1,0 \mathrm{~g}$

- aroma de menta. .q.s.

- água destilada $1000,0 \mathrm{~mL}$

Foram utilizados $20 \mathrm{ml}$ de saliva artificial por espécime, ou seja, na proporção de $2 \mathrm{ml}$ de solução por $\mathrm{mm}^{2}$ de superfície de esmalte exposta para cada bloco. Os espécimes ficaram imersos na saliva artificial, armazenados individualmente em recipientes plásticos tampados, em estufa para cultura (FANEM 502 - FANEM, São Paulo), a $37^{\circ} \mathrm{C}$, por períodos de tempo diferentes, constituindo os grupos MIII e DII (1 hora), MIV e DIII (24 horas) e MV e DIV (7 dias). A saliva artificial era renovada diariamente.

\subsection{Análise da microdureza superficial após tratamento pela saliva artificial}

Foi avaliada a microdureza superficial de cada espécime após a permanência em saliva artificial por períodos de 1h, 24hs e 7 dias, seguindo a metodologia descrita no item 4.4. 


\subsection{Avaliação do desgaste após tratamento pela saliva artificial}

Foi avaliado o desgaste de cada espécime após a permanência em saliva artificial por períodos de $1 \mathrm{~h}, 24 \mathrm{hs}$ e 7 dias, seguindo a metodologia descrita no item 4.8.

\subsection{Análise estatística}

Os valores da microdureza superficial foram analisados a partir de uma comparação direta dos espécimes antes e após a simulação da profilaxia e antes e após a imersão em saliva artificial através da Análise de Variância a um critério para medidas repetidas e pelo Teste de Tukey para a comparação da variabilidade entre os grupos.

Para os testes de desgaste foi feita uma comparação direta dos espécimes antes e após a simulação da profilaxia e antes e após a imersão em saliva artificial através da Análise de Variância a um critério para medidas repetidas e pelo Teste de Tukey para a comparação da variabilidade entre os grupos. 


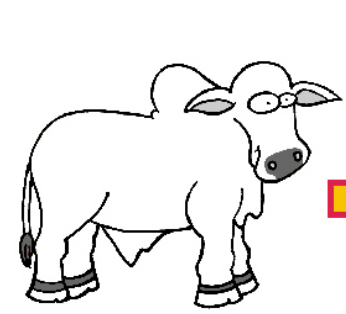

Boi

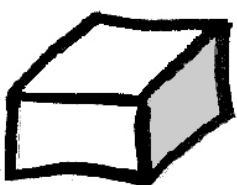

Fragmento hígido<smiles>C1CCC2CCCC(C1)C2</smiles>

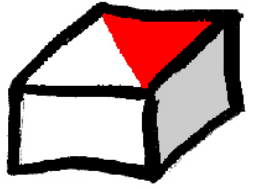

Proteção do fragmento (esmalte de unha)

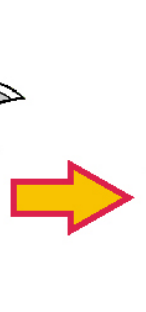

Incisivo bovino

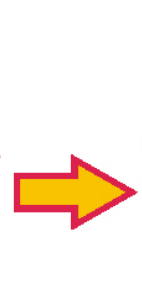

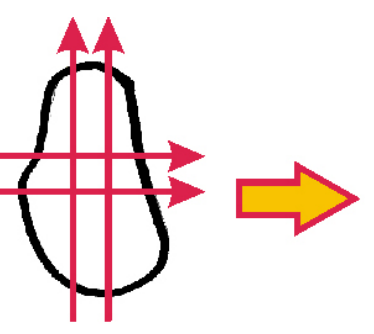

Coroa seccionada

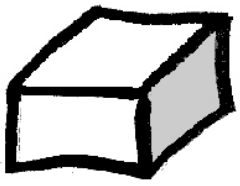

Fragmento
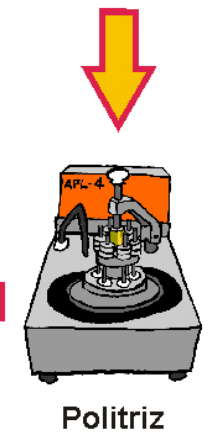
(microdurômetro)
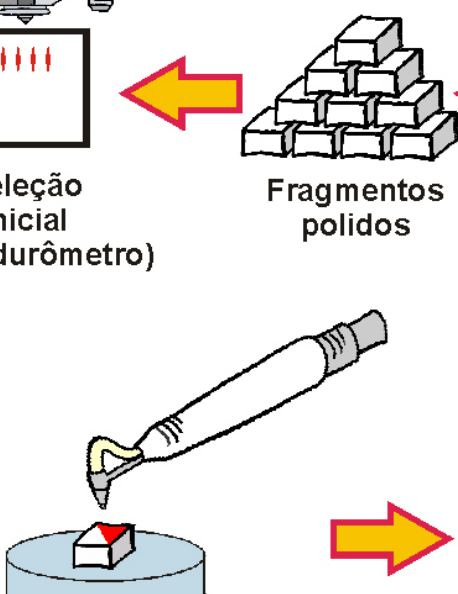

Profilaxia
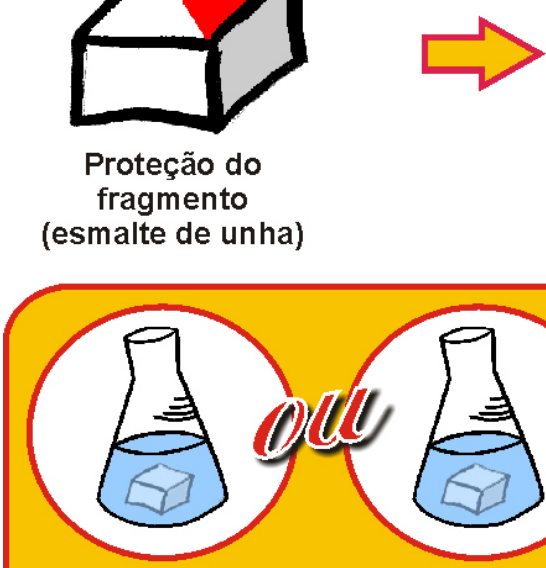

1 hora

Imersão em saliva artifical
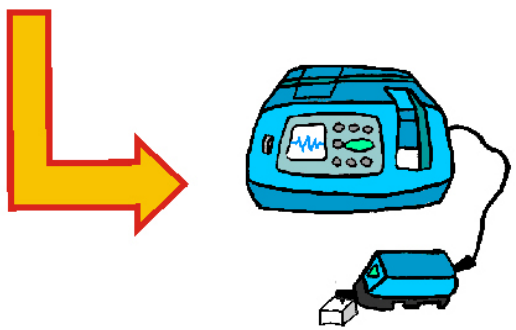

Avaliação final do desgaste
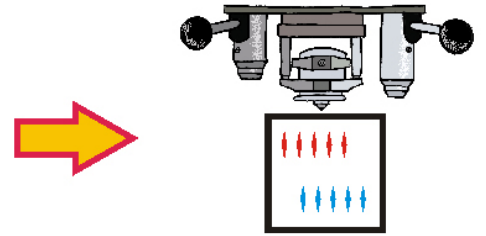

Avaliação final da microdureza

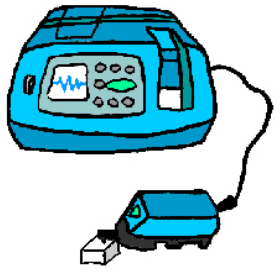

Desgaste Inicial

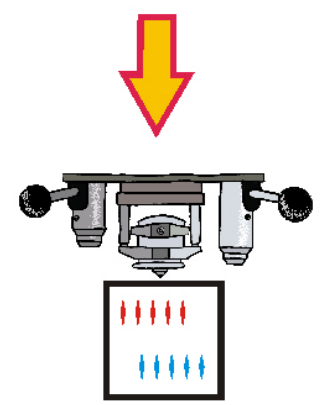

Microdureza após a profilaxia

FIGURA 1 - Delineamento experimental 


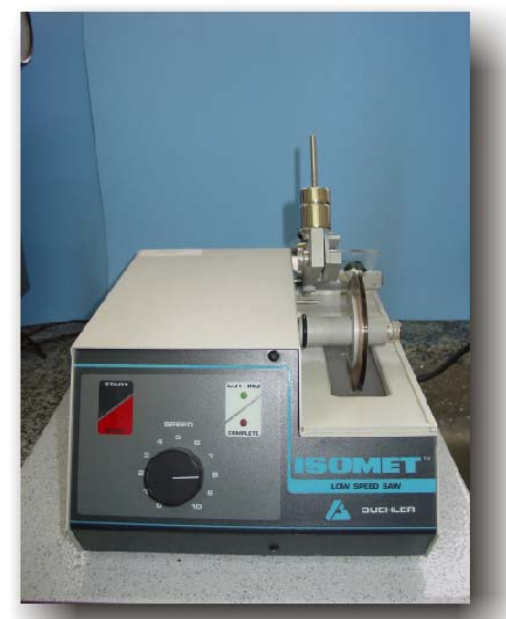

FIGURA 2- Aparelho de corte de precisão

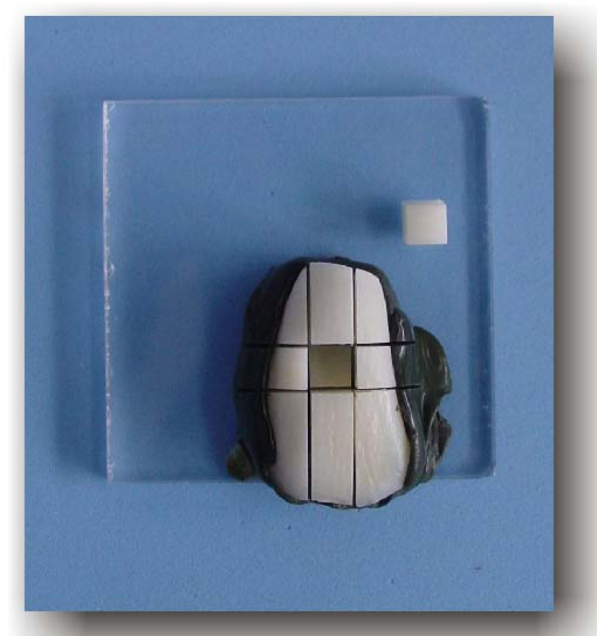

FIGURA 3- Espécime obtido através da coroa seccionada

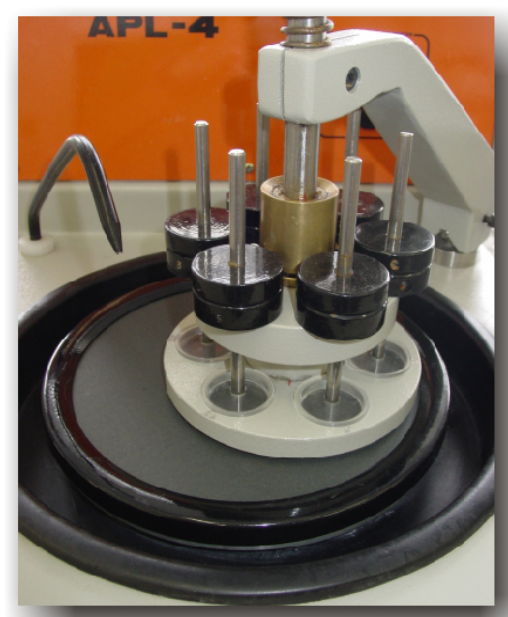

FIGURA 4- Politriz Metalográfica

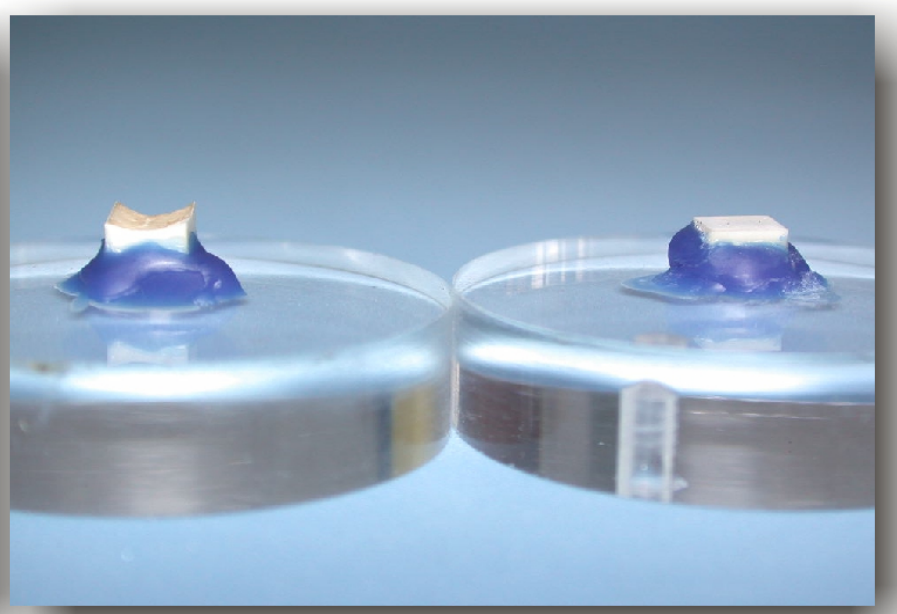

FIGURA 5- Espécime antes e após a planificação da dentina

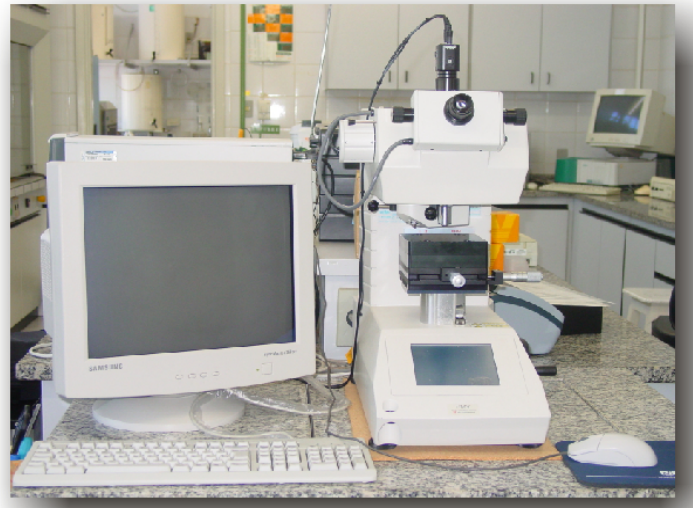

FIGURA 6- Microdurômetro

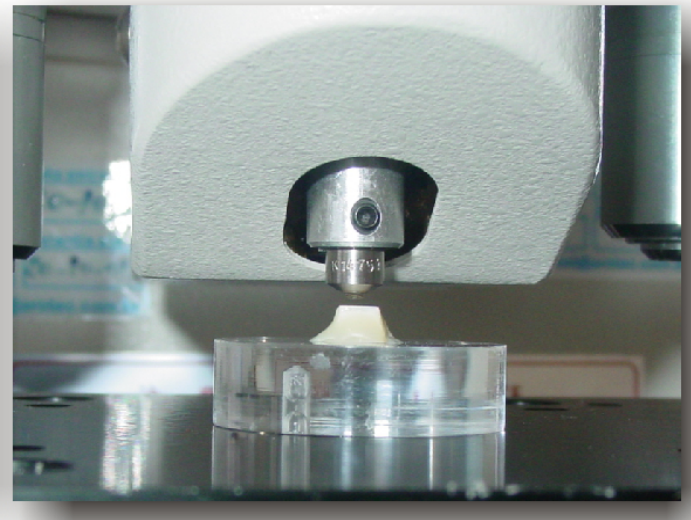

FIGURA 7- Penetrador diamantado tipo KNOOP 


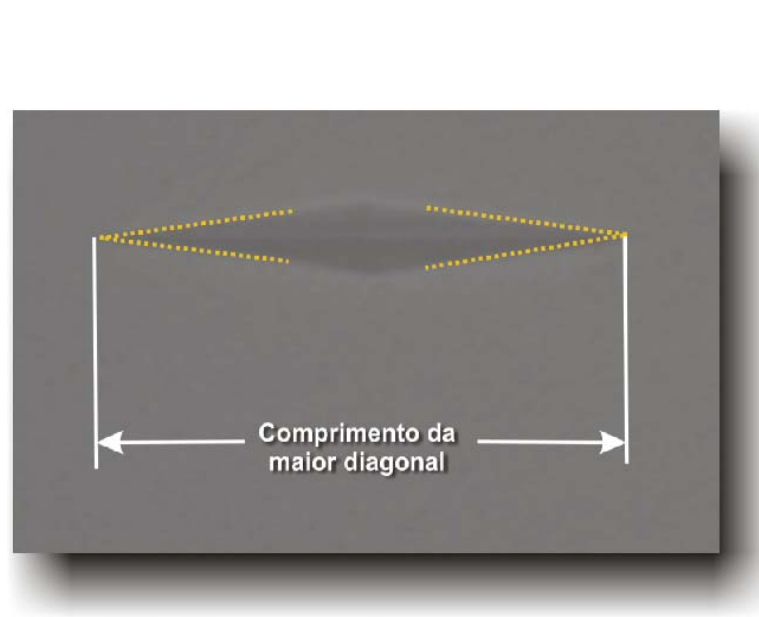

FIGURA 8- Impressão do penetrador

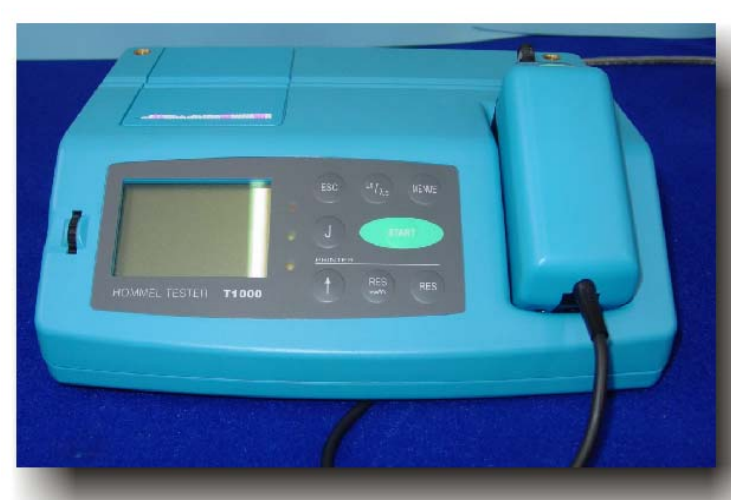

FIGURA 10- Rugosímetro

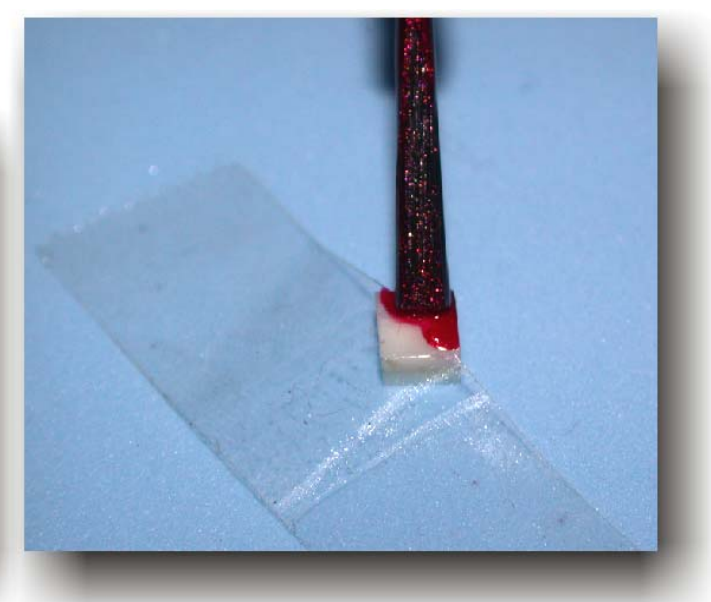

FIGURA 9- Aplicação do esmalte de unha no espécime

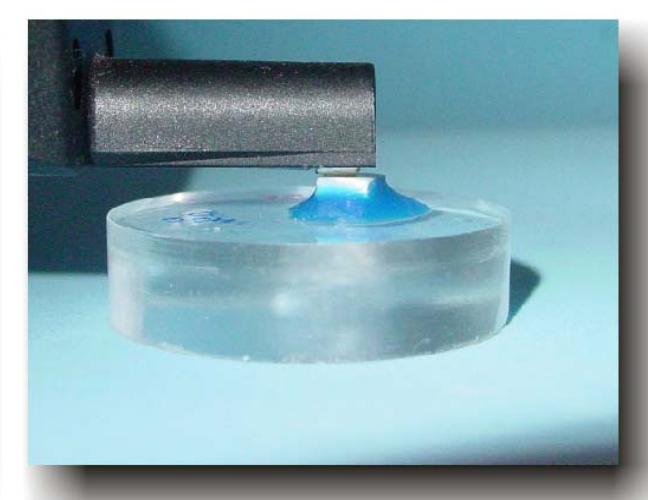

FIGURA 11- Ponta apalpadora do Rugosímetro

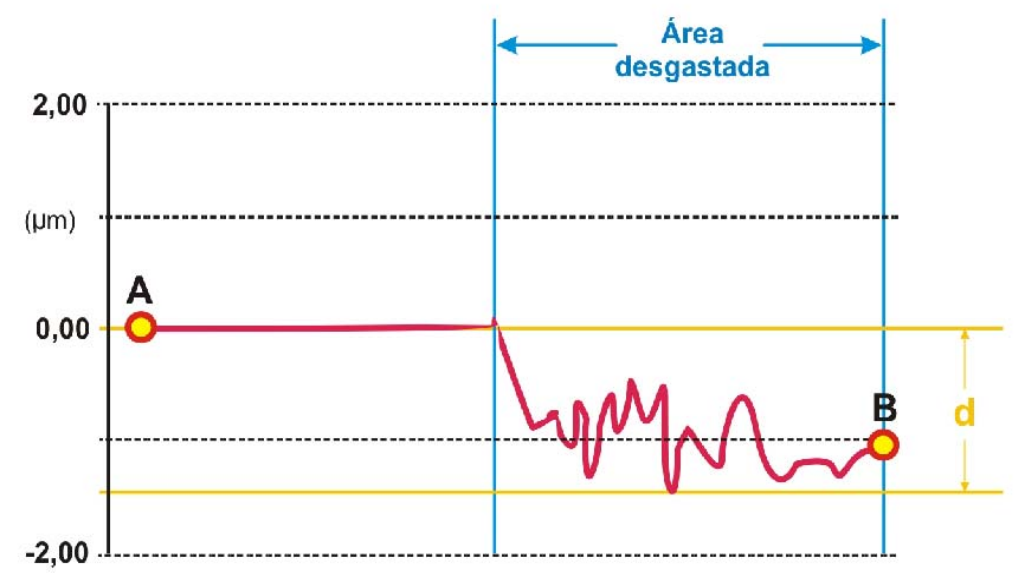

FIGURA 12- Representação do desgaste da superfície testada 


$$
5 \text { Resultados }
$$

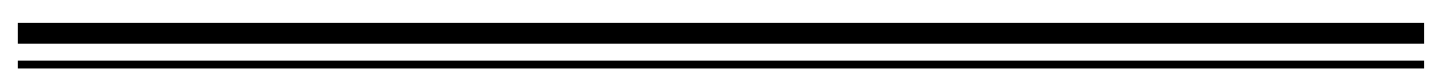




\section{Resultados}

\subsection{Da microdureza superficial}

Os valores da microdureza superficial do esmalte bovino, em KHN, nas diferentes fases do experimento: sem tratamento (G MI), após a simulação da profilaxia com jato de bicarbonato de sódio (G MII), e após a subseqüente imersão em saliva artificial por uma hora (G MIII), 24 horas (G MIV) e sete dias (G MV), podem ser vistos na TABELA 1 e na FIGURA 13.

TABELA 1 - Valor da média, em KHN, da microdureza superficial inicial, após a simulação da profilaxia e após a imersão em saliva artificial nos diferentes tempos de tratamento

\begin{tabular}{lll} 
& Média & Desvio padrão \\
\hline Grupo MI & 359,80 & 22,41 \\
\hline Grupo MII & 335,46 & 32,94 \\
\hline Grupo MIII & 369,20 & 26,01 \\
\hline Grupo MIV & 377,73 & 21,30 \\
\hline Grupo MV & 341,86 & 26,04 \\
\hline
\end{tabular}




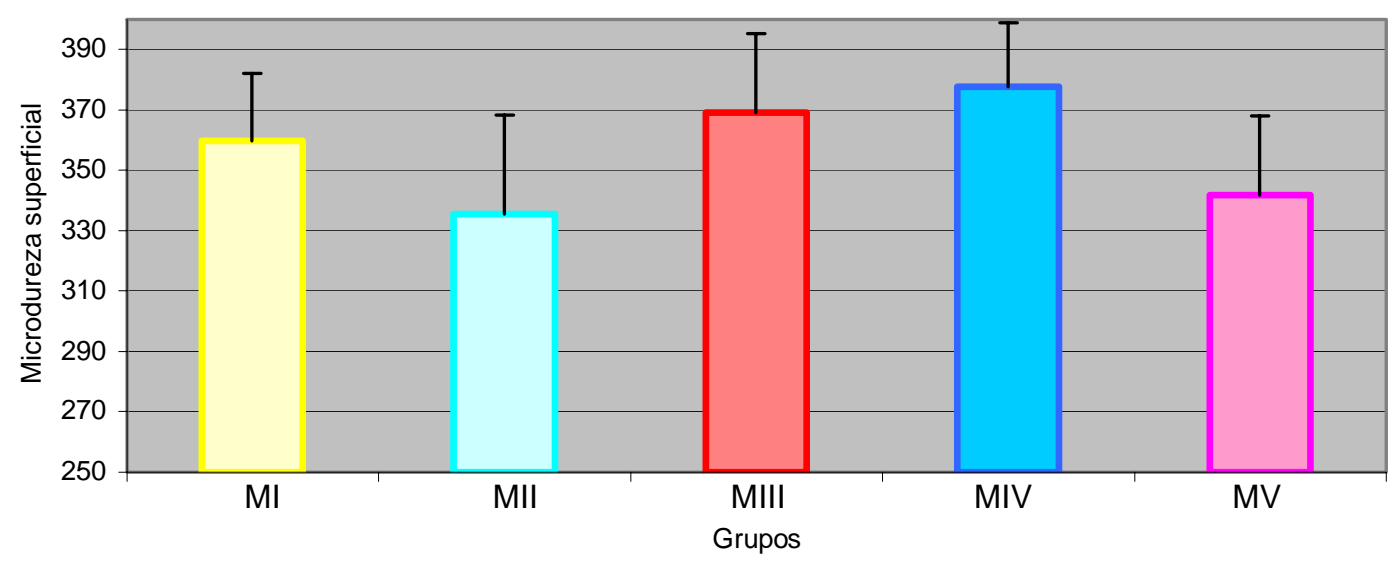

FIGURA 13 - Gráfico dos valores médios da microdureza superficial do esmalte (KHN) antes e após a simulação da profilaxia e após a imersão em saliva artificial nos diferentes tempos de tratamento

Houve uma diminuição, estatisticamente significante, nos valores da microdureza superficial do esmalte após o tratamento com jato de bicarbonato de sódio (G MII), quando comparado à microdureza superficial inicial (G MI) (TABELA 2).

Os dados mostraram que a permanência dos espécimes em saliva artificial seja por uma hora (G MIII), 24 horas (G MIV) ou sete dias (G MV), permitiu que a microdureza superficial do esmalte, que ficou baixa após a profilaxia (G MII), voltasse à condição inicial, pois os valores, tanto do grupo MIII, como do grupo MIV e do grupo MV, não tiveram diferenças estatisticamente significantes em relação aos valores da microdureza superficial inicial (G MI) (TABELA 2).

Considerando o período de tempo de imersão dos espécimes em saliva, não houve diferença estatisticamente significante na microdureza superficial do esmalte do grupo MIII (1 hora) comparado à do grupo MIV (24 horas). No entanto, a microdureza superficial do grupo MV foi menor que a desses grupos (TABELA 2). 
TABELA 2 - Comparação entre os valores médios de microdureza superficial - Teste de Tukey

\begin{tabular}{lllll} 
& Grupo MII & Grupo MIII & Grupo MIV & Grupo MV \\
\hline Grupo MI & $0,006449^{\star}$ & 0,648780 & 0,081370 & 0,081370 \\
\hline Grupo MII & $0,000200^{\star}$ & $0,000128^{\star}$ & 0,882844 \\
\hline Grupo MIII & & 0,725777 & $0,001878^{\star}$ \\
\hline Grupo MIV & & & $0,000155^{\star}$
\end{tabular}

*Diferença estatisticamente significante

\subsection{Do desgaste}

A TABELA 3 e FIGURA 14 contêm os valores médios, em $\mu \mathrm{m}$, do desgaste observado no esmalte bovino, após o procedimento de simulação da profilaxia com o jato de bicarbonato de sódio (G DI) e após a subseqüente imersão em saliva artificial por uma hora (G DII), 24 horas (G DIII) e sete dias (G DIV).

TABELA 3 - Valores da média em $\mu \mathrm{m}$, do desgaste após a simulação da profilaxia e após a imersão em saliva artificial nos diferentes tempos de tratamento

\begin{tabular}{lll} 
& Média & Desvio padrão \\
\hline Grupo DI & 0,564 & 0,106 \\
\hline Grupo DII & 0,519 & 0,103 \\
\hline Grupo DIII & 0,441 & 0,096 \\
\hline Grupo DIV & 0,428 & 0,084 \\
\hline
\end{tabular}




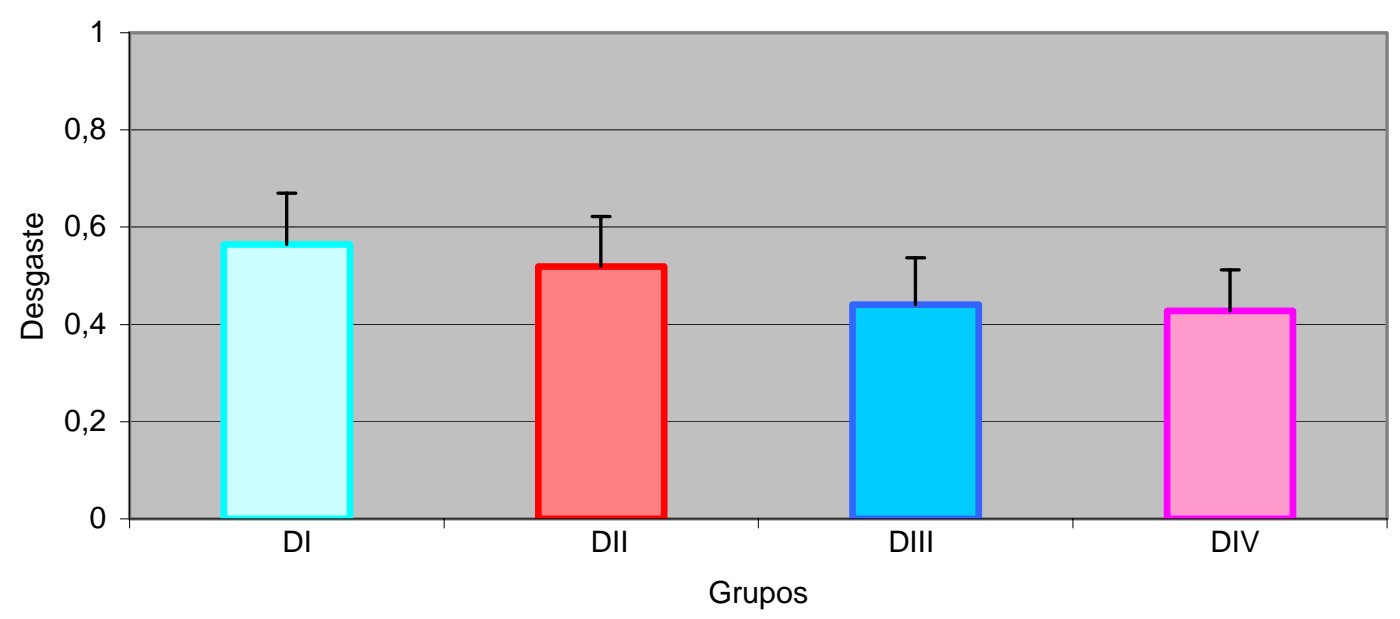

FIGURA 14 - Gráfico dos valores das médias do desgaste do esmalte $(\mu \mathrm{m})$ após a simulação da profilaxia e após a imersão em saliva artificial em diferentes tempos de tratamento

A simulação da profilaxia (G DI) provocou um desgaste no esmalte, da ordem de 0,564 $\mu \mathrm{m}$, que foi reparado pelo tratamento em saliva. Com uma hora de imersão dos espécimes em saliva (G DII) o valor do desgaste já diminuiu para 0,519 $\mu \mathrm{m}$ (TABELA 3), mas a diferença em relação ao obtido após a simulação da profilaxia (G DI) não foi estatisticamente significante (TABELA 4).

O tratamento pela saliva por 24 horas (G DIII) e por sete dias (G DIV) deu melhores resultados, pois os valores do desgaste nesses grupos foram menores que o valor encontrado nos espécimes logo após a realização da simulação da profilaxia (G DI) em um nível estatisticamente significante (TABELA 4).

Não houve diferença estatisticamente significante entre o desgaste do grupo DIII e do grupo DIV. 
TABELA 4 - Comparação entre os valores médios do desgaste - Teste de Tukey

\begin{tabular}{llll} 
& Grupo DII & Grupo DIII & Grupo DIV \\
\hline Grupo DI & 0,454708 & $0,001144^{\star}$ & $0,000397^{\star}$ \\
\hline Grupo DII & & 0,057273 & $0,018782^{\star}$ \\
\hline Grupo DIII & & 0,968025 \\
\hline
\end{tabular}

*Diferença estatisticamente significante 


\section{Discussão}

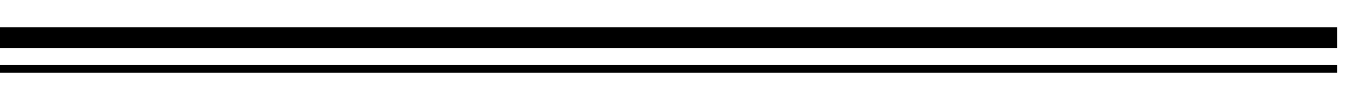




\section{Discussão}

Sendo indiscutível a importância do controle da placa na prevenção da cárie ${ }^{12,39,49}$ e da gengivite ${ }^{12,50}$, inúmeras pesquisas se desenvolvem em busca da medida mais eficaz no alcance desse objetivo.

Conquanto, o controle químico, dentro de suas indicações precisas, tem se mostrado efetivo, os inconvenientes que acompanham seu emprego ${ }^{86}$ fazem com que a primeira opção de medida de controle de placa, para a população em geral, recaia em sua remoção mecânica.

Os resultados com esse procedimento mostram-se muito favoráveis, seja pela escovação dentária ${ }^{15,46}$ ou pela profilaxia profissional ${ }^{15,} 25,39,42,50$, $56,63,64,74,82,83$ ou pela associação dessas medidas ${ }^{13,} 49$.

Dentre os métodos de profilaxia profissional, quando se compara a eficácia na remoção de placa obtida pela taça de borracha e pasta de pedra pomes com a de jato de bicarbonato de sódio, embora alguns pesquisadores considerem o desempenho de ambos semelhante ${ }^{25,74}$, outros apontam a superioridade do jato de bicarbonato de sódio ${ }^{42}, 82,83$.

Este procedimento tem se mostrado excelente na remoção de placa das superfícies vestibulares, linguais e proximais, bem como nas fossas e fissuras dos dentes ${ }^{25,42,50,56,63,64,74,82,83}$. Também, é bastante efetivo na presença de aparelhos ortodônticos ${ }^{50,63}$, promove a melhora dos casos de gengivite em fase inicial e contribui para a recuperação do epitélio em pacientes com GUNA ${ }^{50}$.

Quanto ao possível efeito traumático do jato de bicarbonato de sódio sobre a gengiva saudável, tem sido relatada sua ocorrência ${ }^{58}{ }^{83}$. No entanto, esse trauma não é diferente do causado pela taça de borracha ${ }^{25,58} \mathrm{e}$, em ambos os casos, o retorno da saúde gengival acontece em poucos dias após os procedimentos de profilaxia ${ }^{58,83}$.

Contudo, é sabido que o procedimento de profilaxia profissional, se por um lado remove a placa, prevenindo a cárie e a gengivite, por outro 
promove alterações nos tecidos duros dos dentes ${ }^{1,9}$, 10, 11, 14, 16, 20, 21, 24, 29, 31 , 32, 33, 40, 42, 53, 61, 69, 88 . Essas alterações no esmalte podem ser comparadas à perda mineral que ocorre em uma lesão inicial de cárie ${ }^{72}$.

Sendo inquestionável a necessidade, em muitos casos, da realização periódica da profilaxia, ela pode ser recomendada, a despeito de provocar a abrasão nos dentes, pois este inconveniente pode ser reparado, contandose com o poder remineralizador que a saliva desempenha, repondo o cálcio e os fosfatos que são removidos dos tecidos dentários ${ }^{2,43,78,66}$.

No presente trabalho, foi feita a quantificação do desgaste e da microdureza superficial do esmalte, associada à simulação da profilaxia com jato de bicarbonato de sódio, em dentes bovinos, bem como a avaliação do tempo necessário de atuação da saliva para que a reparação dessas alterações ocorra.

$\mathrm{Na}$ simulação da profilaxia, a aplicação do jato foi feita a uma distância de $5 \mathrm{~mm}$ do esmalte, durante dez segundos, com uma angulação de $90^{\circ}$, sem interrupção.

A distância de $5 \mathrm{~mm}$ do jato à superfície do esmalte bovino é a que mais se aproxima do que é feito em clínica e da que tem sido empregada nas pesquisas, onde a distância usada varia de 4 a 5mm 11 , 16, 29, 32, 40, 61, 69, 75 .

O tempo de dez segundos da aplicação do jato é considerado excessivo, pois, segundo AGGER; HOSTED-BINDSLEV; HOVGAARD ${ }^{1}$ (2001), não se leva mais que 0,5 segundo em cada área do dente, quando se realiza este procedimento em clínica. Mas, em pesquisas para quantificar o efeito abrasivo da profilaxia emprega-se um tempo maior, que tem sido de cinco segundos $^{1,55,75}$, dez segundos ${ }^{29,40,55}, 30$ segundos $^{11,16,32,64,69}$ e até um minuto ${ }^{42}$.

Quanto à angulação de $90^{\circ}$ aqui usada, foi a mesma adotada por MARTA $^{55}$ (1997), HONÓRIO ${ }^{40}$ (2003), AGGER; HOSTED-BINDSLEV; HOVGAARD $^{1}$ (2001), FRAGA ${ }^{29}$ (2005), mas também tem sido relatado o ângulo de $60^{\circ} 32$ e variação de $60^{\circ}$ a $80^{\circ} 61$ na aplicação do jato de bicarbonato de sódio. 
Apenas uma parte do corpo de prova ficou exposta à ação do jato de bicarbonato de sódio, pois metade da superfície de cada espécime foi protegida com esmalte de unha. Isso permitiu a comparação do esmalte tratado e não tratado, por ocasião dos testes de avaliação do desgaste realizados posteriormente.

A opção pela utilização de dentes bovinos, nesta pesquisa, encontrou suporte na literatura, onde foram empregados como alternativa aceitável ao esmalte humano, em estudos de desenvolvimento da cárie e sua prevenção $6,7,17,21,23,26,28,29,47,54,57,60,62,89,90$. Também, têm sido usados em estudos de adesividade ${ }^{65}$ e de erosão $2,4,5,9,10,56$.

Comparativamente ao dente humano, o bovino é mais solúvel ${ }^{17,60,89}$, mais poroso ${ }^{6,57,89}$ e talvez por isso nele seja mais rápida a progressão da cárie $^{6,28,57}$ e da erosão ${ }^{4}$ o que encurta o tempo de experimentos com desremineralização. A microestrutura do dente bovino é similar à do humano ${ }^{65} \mathrm{e}$ sua composição é mais homogênea ${ }^{54,57,89}$, mas varia de uma espécie para outra e também do decíduo para o permanente.

Para a realização do presente trabalho importou muito o fato de que os dentes bovinos são encontrados com mais facilidade que os humanos, em bom estado e em quantidade ${ }^{57}$. Apresentam superfícies planas e amplas $^{57}$, que são reprodutíveis ${ }^{54,65}$, se prestando bem para ensaios de microdureza ${ }^{54}$. Neste esmalte, os comprimentos das impressões nos testes de microdureza são maiores que nos humanos ${ }^{21}$.

A metodologia seguida para obtenção dos espécimes de esmalte bovino teve por base a utilizada em trabalhos anteriores ${ }^{29,40,56,62,75}$.

Após a seleção dos dentes bovinos, suas raízes foram removidas e em seguida obtiveram-se os espécimes de esmalte de $4 \mathrm{~mm} \times 4 \mathrm{~mm}$, da porção mais plana e central da coroa, por meio de uma secção dupla cervicoincisal e mesiodistal. Embora, sendo o esmalte bovino um tecido de grande homogeneidade, teve-se o cuidado de padronizar o local da coroa a ser seccionada para obtenção dos fragmentos, diminuindo a possibilidade de interferência decorrente de possíveis variações de dureza superficial em vários locais de um mesmo dente. 
O esmalte bovino foi planificado e polido antes dos tratamentos, pois é sabido que as variações nas medidas da microdureza são menores, quando a superfície a ser testada não apresenta curvaturas ${ }^{18,60}$. A obtenção de uma superfície plana foi facilitada pela pequena curvatura que os incisivos bovinos apresentam, o que também possibilitou remover apenas uma quantidade pequena de tecido na obtenção dessa superfície plana.

Além de aplainada, a superfície do esmalte foi polida, já que esse procedimento tem sido recomendado para a realização dos testes de microdureza superficial ${ }^{21,80}$, pois gera uma superfície mais reprodutível.

Outra razão pela qual foi realizado o polimento é que o esmalte bovino tem uma superfície extremamente irregular e rugosa e as perdas estruturais oriundas de procedimentos profiláticos são menores que essas irregularidades $^{69,80,88,91}$. O polimento permitiu a visualização exata da área desgastada.

Os efeitos abrasivos dos diferentes métodos de profilaxia são avaliados através de várias metodologias.

Para uma análise qualitativa, tem sido empregada a microscopia eletrônica de varredura $^{1,11,16,20,29,32,40,42,55,61,69,85}$.

Para uma avaliação quantitativa da perda de estrutura dentária, pode ser empregada a microscopia ótica com foco graduado ${ }^{11}$, mas, para ser confiável, depende da análise de dois ou mais examinadores, já que os resultados se baseiam em interpretações pessoais dos valores.

Uma outra forma de avaliação quantitativa pode ser a que foi feita por GALLOWAY; PASHLEY ${ }^{31}$ (1987), que colocaram cera sobre o local desgastado a qual depois de removida foi pesada e em função da densidade do dente e da cera, a perda de estrutura foi determinada. Esse procedimento, no entanto, não quantifica desgastes microscópicos.

Outras metodologias empregadas para quantificação do desgaste são a espectrofotometria do produto da profilaxia ${ }^{20,88}$, a contagem radioativa do material desgastado $^{14,33,35,53,80}$, e a perfilometria ${ }^{1,9,10,14,24,29,32,40,69,75,85}$. Esta última foi desaconselhada por HEFFERREN ${ }^{35}$ (1976), porque os aparelhos são delicados e caros. 
O método da marcação radioativa para mensuração do desgaste é rápido e preciso, mas, a perfilometria tem sido preferida, por ser um procedimento simples e direto de avaliação que não altera a superfície testada, permitindo a realização posterior de outras etapas do experimento. Por esses motivos, a perfilometria foi o método escolhido para realizar o presente trabalho ${ }^{1,9,10,14,24,29,32,40,69,75,85}$.

O perfil da superfície do esmalte foi avaliado a partir de um rugosímetro, que percorre essa superfície, passando por áreas de esmalte tratado e não tratado. Como o esmalte bovino foi polido, o perfil da superfície não tratada pelo jato de bicarbonato de sódio se assemelhava a uma linha reta e, portanto, as alterações dessa linha, observadas no esmalte expressaram o resultado da simulação da profilaxia.

O resultado do desgaste foi obtido, medindo-se a distância da linha média do gráfico representativo do perfil do esmalte, correspondente ao plano do espécime, até o maior vale correspondente à área desgastada.

As avaliações foram feitas em cinco áreas distintas para que a média dos valores obtidos, dada em $\mu \mathrm{m}$, expressasse a quantidade de desgaste mais próxima da realidade. Outros pesquisadores como HONÓRIO ${ }^{40}$ (2003) e FRAGA ${ }^{29}$ (2005) também realizaram mais de uma medida de desgaste em cada bloco.

Pela literatura, pode-se inferir que a quantidade de desgaste oriundo da profilaxia em dentes humanos é bem menor em esmalte do que em dentina $^{20,33,61,80}$ ou em cemento ${ }^{11,61,69}$.

No entanto, mesmo não sendo tão expressiva, a abrasão do esmalte tem sido constatada após procedimentos de profilaxia. Assim, com o uso da taça de borracha e de pedra-pomes foi relatado haver desgaste em esmalte humano hígido ${ }^{42,53,80,85,88,91}$. Embora haja relato de desgaste no esmalte de dente decíduo com 0 uso de jato de bicarbonato de sódio ${ }^{42}$, não foi constatada abrasão em esmalte hígido de dente permanente por BOYDE ${ }^{16}$ (1984), NEWMAN; SILVERWOOD; DOLBY ${ }^{61}$ (1985), GALLOWAY; PASHLEY $^{31}$ (1987), MARTA ${ }^{55}$ (1997), com esse procedimento. O desgaste ocorreu em dentina e cemento ${ }^{1,11,69,31}$ e em esmalte desmineralizado ${ }^{16}$. 
Como o esmalte humano é menos poroso que o bovino ${ }^{6,57,89}$, resultados de desgaste provocado sobre ambos não devem ser comparados, sem reserva.

Em esmalte bovino, foi avaliado o desgaste provocado pelo jato de bicarbonato de sódio $^{29}, 32,40$, pela taça de borracha ${ }^{32}$ e pela escova de Robinson ${ }^{40}$, essas últimas com pasta de pedra pomes. GERBO et al. ${ }^{32}$ (1993) não observaram desgaste, enquanto HONÓRIO ${ }^{40}$ (2003) e FRAGA ${ }^{29}$ (2005), constataram a presença de rugosidade, como efeito da simulação da profilaxia, que foi maior no esmalte previamente descalcificado que no hígido.

No presente trabalho, foi constatado um desgaste médio, da ordem de 0,564 $\mu \mathrm{m}$, após a simulação de profilaxia com jato de bicarbonato de sódio. Este valor é superior ao relatado por HONÓRIO ${ }^{40}$ (2003), que foi de $0,418 \mu \mathrm{m}$ e por FRAGA ${ }^{29}$ (2005) que encontrou um desgaste de 0,319 $\mu \mathrm{m}$.

É sabido que pequenas alterações da superfície do esmalte podem refletir-se em suas propriedades físicas e, sendo a microdureza uma delas, questionou-se o quanto a consistência e dureza do esmalte podem diminuir pela realização da profilaxia. A resposta para essa questão foi um dos objetivos deste trabalho.

A avaliação da microdureza tem sido usada para constatar alterações dessa propriedade física do esmalte, após ter sido exposto a procedimentos ou processos que alterem os minerais de sua estrutura. É um dos melhores métodos para identificação de lesões cariosas.

Essa avaliação vem sendo feita há praticamente um século, com o auxílio dos mais diversos aparelhos ${ }^{36,37,46,71}$, mas, os métodos existentes até a década de 30 , baseados na resistência à penetração, não eram adequados para a estrutura dentária ${ }^{36}$. Os aparelhos faziam uso de pontas penetradoras que, muitas vezes causavam uma distorção destrutiva do material testado, permitindo apenas uma análise qualitativa da dureza.

Até os dias de hoje, o teste de microdureza mais usado em

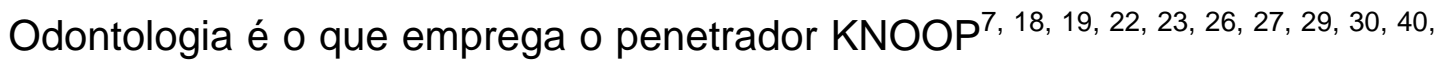
$41,45,46,52,56,59,60,70,75,79,84,90$. 
Esse foi o método de escolha para o presente trabalho, pois permite detectar de forma rápida e sensível as alterações nas estruturas dentárias, com pequenas cargas, em superfícies pequenas e em áreas friáveis e elimina as variações humanas, já que a aplicação e remoção da carga são feitas eletronicamente. O penetrador KNOOP realiza impressões com dimensões bem definidas e reproduzíveis, não produz distorções e não danifica a estrutura do esmalte ${ }^{59}$, permitindo avaliar uma sucessão de alterações ocorrendo num mesmo espécime.

Nesta pesquisa, a microdureza foi medida nos blocos de esmalte bovino, após sua planificação e polimento, para padronização da amostra: 15 espécimes, cujos valores de microdureza não estavam 10\% abaixo ou acima da média de todos os blocos, foram selecionados. Esses valores de microdureza inicial serviram para comparação dos valores obtidos após a simulação da profilaxia e após a imersão dos blocos em saliva, para concluir sobre os efeitos dos tratamentos na microdureza superficial do esmalte.

Esta pesquisa foi realizada com os mesmos 15 espécimes de esmalte bovino que se submeteram a tratamentos sucessivos. Isso foi possível em razão da metodologia empregada. No teste de desgaste foi usada a perfilometria, que não altera a superfície testada permitindo a realização posterior de outras etapas do experimento. No teste de microdureza foi usado o penetrador KNOOP, que também não produz distorções e não danifica a estrutura do esmalte ${ }^{59}$. Esses métodos possibilitaram avaliar uma sucessão de alterações ocorrendo num mesmo espécime.

Para o teste de microdureza, em cada espécime foram realizadas cinco impressões aleatoriamente, englobando diferentes áreas da superfície, na porção central dos fragmentos. Obtendo-se a média dos valores das impressões, tentou-se afastar a interferência de possíveis variações que possam correr na microdureza de diferentes áreas de um mesmo dente. Essas variações foram descritas em esmalte humano por PURDELL-LEWIS; GROENVELD; ARENDS ${ }^{73}$ (1976). Também fizeram cinco impressões em cada bloco KIELBASSA ${ }^{46}$ (1999), NUNES ${ }^{62}$ (2002), HONÓRIO ${ }^{40}$ (2003), $\operatorname{RIOS}^{75}$ (2004) e FRAGA 29 (2005). 
A carga estática utilizada no penetrador foi de $25 \mathrm{~g}$, a mesma de RIOS $^{75}$ (2004) e FRAGA ${ }^{29}$ (2005), considerada adequada para esmalte bovino, embora a maioria dos pesquisadores tenha empregado a carga estática de $50 \mathrm{~g} 22,40,46,52,56,90$, e alguns de $500 \mathrm{~g}^{7,18,60}$. O tempo de aplicação da carga foi de cinco segundos, igualmente ao de HONÒRIO ${ }^{40}$ (2003) RIOS$^{75}$ (2004) e FRAGA ${ }^{29}$ (2005), nos quais o presente trabalho baseou sua metodologia. Outros pesquisadores usaram o tempo de sete segundos $^{56}$, dez segundos ${ }^{7,18,60}, 15$ segundos $^{22}$ e 30 segundos $^{46}$.

Neste trabalho, o valor médio da microdureza superficial inicial do esmalte bovino, antes de qualquer tratamento, foi de 359,80 KHN, sendo muito próximo ao valor relatado por NEWBRUN; TIMBERLAKE; PIGMAN ${ }^{60}$ (1959), sendo superior ao valor relatado por FRAGA ${ }^{29}$ (2005), que foi de 300,47 KHN e inferior ao de HONÓRIO ${ }^{40}$ (2003), citado como sendo 394,0 KHN.

Em esmalte humano hígido, os valores de microdureza KNOOP que a literatura relata são variáveis: 250 a $500 \mathrm{KHN}^{18}$; $325 \mathrm{KHN}$ e $367 \mathrm{KHN}^{50} ; 343$ $\mathrm{KHN}^{22} ; 367 \mathrm{KHN}^{60} ; 317 \mathrm{KHN}^{7} ; 350 \mathrm{KHN}^{79} ; 300$ a $400 \mathrm{KHN}^{59}$.

Vê-se que a microdureza superficial do esmalte hígido, aqui obtida, está dentro da faixa de 300 a $400 \mathrm{KHN}$, que é onde se situam os valores encontrados na maioria dos casos, tanto em esmalte humano, quanto bovino.

Pelo tratamento de simulação da profilaxia com jato de bicarbonato de sódio a microdureza do esmalte bovino diminuiu de 359,80 KHN para 335,46 KHN, sendo a diferença estatisticamente significante. Houve, portanto, uma perda de dureza do esmalte, além do desgaste constatado por meio do rugosímetro, como efeito da simulação de profilaxia.

Em pesquisa realizada por FRAGA ${ }^{29}$ (2005), a aplicação do jato de bicarbonato de sódio não alterou a microdureza superficial do esmalte bovino hígido, mas, seu valor médio no esmalte com lesão de cárie artificial aumentou em nível significante, após a simulação da profilaxia. É bem possível que pelo procedimento tenha ficado exposta a camada mais interna da lesão, a qual tem maior resistência. 
É difícil explicar como, trabalhando em condições semelhantes, houve discordância de resultados quanto à microdureza superficial do esmalte hígido observada na corrente pesquisa e no trabalho de FRAGA ${ }^{29}$ (2005).

A ausência de outros trabalhos prévios na literatura, buscando o efeito da aplicação do jato de bicarbonato de sódio no esmalte, no que se refere à microdureza, impossibilita uma comparação dos valores encontrados neste estudo. Isto torna difícil afirmar se o resultado aqui obtido era o esperado ou não.

Uma vez que neste estudo in vitro foram constatadas mudanças no esmalte dental bovino, sob a ação do jato de bicarbonato de sódio, é importante considerar que se essas alterações ocorrerem na clínica, ainda que sejam mínimas, pode-se esperar o retorno às condições iniciais, simplesmente pelo fato que o dente se encontra banhado pela saliva.

A saliva restitui a integridade dos tecidos, repondo o cálcio e fosfato perdidos. Neste processo, os espaços intercristais que foram abertos se fecham, devido a uma nova formação de cristais (in vivo) ou pela precipitação de componentes salivares (in vitro) ${ }^{51}$.

Há muitos trabalhos demonstrando o resultado do processo que ocorre quando o esmalte desmineralizado é exposto à saliva supersaturada em fosfatos e cálcio. As pesquisas têm sido feitas com saliva natural e artificial.

A saliva artificial tem se prestado para muitas investigações ${ }^{2,5,10,29,62}$ e é um fato inconteste que ela remineraliza o dente, da mesma forma que ocorre in vivo ${ }^{5}$.

Neste trabalho, utilizaram-se $20 \mathrm{ml}$ de saliva artificial para cada bloco de $4 \mathrm{~mm} \times 4 \mathrm{~mm}$, que foi trocada diariamente, mantendo-se os recipientes, com os espécimes nela imersos, em estufa a $37^{\circ} \mathrm{C}$. Para definir este procedimento, baseou-se nas razões apresentadas por FRAGA ${ }^{29}$ (2005), que a levaram proceder a remineralização pela saliva nessas condições de volume e temperatura.

Os espécimes foram tratados pela saliva por períodos de uma hora, 24 horas e sete dias. Esses tempos foram estipulados baseados no trabalho 
de FRAGA ${ }^{29}$, já que faltam na literatura informações sobre em que momento os efeitos da saliva já podem ser detectados na reparação das alterações decorrentes da profilaxia em esmalte hígido.

FRAGA $^{29}$ (2005) não conseguiu detectar alterações no valor da microdureza do esmalte hígido, submetido à simulação de profilaxia por jato de bicarbonato de sódio, portanto é natural que o posterior tratamento pela saliva não tenha se refletido nesse valor. Apenas com o período de imersão na saliva por 28 dias houve alteração no desgaste e na microdureza do esmalte.

Já, nesta pesquisa, em que houve uma queda nos valores da microdureza inicial do esmalte após o tratamento pelo jato de bicarbonato de sódio, quando os espécimes ficaram imersos na saliva, pode-se constatar seu efeito na restituição da integridade do tecido.

A imersão dos espécimes em saliva, por apenas uma hora, foi suficiente para que a microdureza adquirisse um valor que não foi diferente, em nível de significância estatística, do inicial. O mesmo ocorreu com a imersão dos blocos em saliva por 24 horas e por sete dias, permitindo afirmar que a reparação das alterações decorrentes da simulação de profilaxia já acontece, após pouco tempo de contato com a saliva.

O tratamento pela saliva também teve efeito reparador no desgaste oriundo do jato de bicarbonato de sódio aplicado no esmalte bovino.

Com uma hora de imersão dos espécimes em saliva, o desgaste de $0,564 \mu \mathrm{m}$ causado pela simulação da profilaxia já diminuiu para $0,519 \mu \mathrm{m}$, embora a diferença não tenha sido estatisticamente significante.

Porém, o tratamento em saliva pelo período de 24 horas, levou a uma

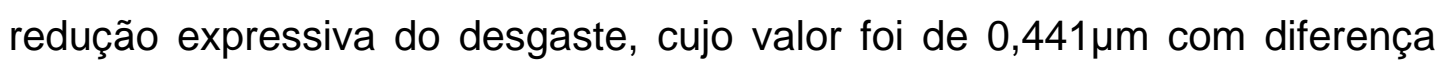
estatisticamente significante do valor encontrado após a aplicação do jato de bicarbonato de sódio.

Não houve vantagem no resultado do desgaste com a extensão do período de imersão dos espécimes em saliva para sete dias, pois ele se apresentou semelhante ao obtido com 24 horas de tratamento. 
Há muita discrepância entre esses resultados e os de FRAGA ${ }^{29}$ (2005), em cujo trabalho o período de quatro horas de imersão na saliva não foi suficiente para alterar a microdureza e o desgaste do esmalte bovino hígido. Apenas com o tratamento de 28 dias dos espécimes na saliva FRAGA $^{29}$ (2005), pode observar efeito estatisticamente significante no desgaste e na microdureza do esmalte bovino hígido. Porém, o intervalo muito grande entre as duas observações (4 horas e 28 dias) não permitiu saber qual foi o tempo necessário para se visualizar um efeito do tratamento.

Já os resultados da corrente pesquisa são coerentes com os de JOHANSSON $^{43}$ (1965). O efeito reparador da saliva, no presente trabalho sobre as alterações na microdureza superficial e no desgaste do esmalte, se revelou no máximo em 24 horas, não havendo benefício adicional com o tempo de sete dias.

No trabalho de JOHANSSON ${ }^{43}$ (1965) em dentes humanos desmineralizados, o processo de remineralização pela saliva ocorreu rapidamente nas primeiras 24 horas, reduziu de intensidade nas 48 horas e não houve incremento de deposição mineral com a imersão em saliva por um período de até três semanas. Uma possível explicação para esse fato é que, com o tempo, deve ocorrer um bloqueio de difusão iônica para o interior do esmalte, em função da deposição mineral em sua camada mais externa.

Essa rapidez na remineralização do esmalte, quando a saliva ou soluções remineralizadoras artificiais com alta concentração de cálcio são utilizadas, foi constatada em revisão de literatura feita por SILVERSTONE ${ }^{77}$ (1977).Também, ÖGAARD; TEN BOSCH ${ }^{66}$ (1994) observaram in vivo que a remineralização na presença de saliva é um processo relativamente rápido.

Embora não se saiba até que ponto os resultados obtidos em pesquisas de laboratório podem ser extrapolados para a realidade clínica, o que se pode observar neste trabalho leva a algumas reflexões sobre a conduta adotada em odontopediatria na prevenção da cárie dentária.

Indiscutivelmente o que se procura é a adoção de métodos e medidas que sejam as mais efetivas possíveis, para impedir o início da cárie e ou bloquear sua progressão com o menor efeito colateral indesejável. 
Assim, certos procedimentos, são comprovadamente eficazes e devem fazer parte da rotina odontopediátrica. Trata-se do cirurgião-dentista se esforçar, ao máximo, para motivar a criança e seus responsáveis a adquirirem hábitos saudáveis de higiene bucal. O uso correto de escova e fio dental, por técnicas adequadas devem ser enfaticamente ensinados pelo profissional à criança e às pessoas que supervisionarão os procedimentos. Ainda, orientação quanto ao controle da dieta com vistas à ingestão de hidratos de carbono, é outro fator que o cirurgião-dentista não pode menosprezar.

Mas, em adição a isso tudo, considerando-se a dificuldade que há para que a criança realmente sinta interesse em realizar o que the é sugerido e ensinado e, também pela inabilidade própria da infância em executar adequadamente a escovação dos dentes, torna-se imprescindível uma remoção mecânica da placa, realizada periodicamente pelo profissional.

O conjunto desses procedimentos, se por um lado leva a um controle efetivo da cárie, por outro pode a cada realização da profilaxia, seja pela taça de borracha ou escova de Robinson mais pasta profilática, seja pelo jato de bicarbonato de sódio, causar uma abrasão na superfície do esmalte.

No entanto, é tranqüilizador poder contar com a própria natureza para reparar essas alterações que ocorrem no esmalte. A saliva que banha os dentes restitui a integridade desse tecido, cujos espaços intercristais abertos anteriormente se fecham devido a uma nova formação de cristais.

Esse processo é acelerado na presença de flúor e o uso de dentifrícios fluoretados tem sido recomendado.

Porém, se o flúor presente no meio bucal acelera o processo de remineralização, não se pode desprezar a possibilidade da ocorrência de fluorose dentária, quando é usado por crianças na fase de formação dos dentes, o que é altamente indesejável.

A indicação de que o processo de remineralização ocorre rapidamente, simplesmente pela ação da saliva saturada de cálcio e de fosfatos, dá segurança ao cirurgião-dentista para realizar a profilaxia quantas vezes for necessária. 


\section{Conclusões}

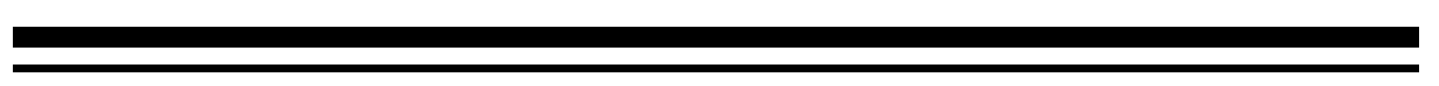




\section{Conclusões}

Com a metodologia desenvolvida neste trabalho, pode-se concluir que, no esmalte do dente bovino:

1. a simulação da profilaxia com jato de bicarbonato de sódio causou um desgaste e uma diminuição da microdureza superficial.

2. a saliva promoveu retorno da microdureza superficial à condição inicial, anterior à simulação da profilaxia e reduziu o desgaste causado por este procedimento.

3. o efeito reparador da saliva sobre as alterações na microdureza superficial causadas pela simulação da profilaxia já ocorreu com uma hora de tratamento, não havendo diferença estatisticamente significante do efeito obtido com 24 horas.

4. o melhor efeito reparador da saliva sobre o desgaste causado pela simulação da profilaxia ocorreu com 24 horas de tratamento.

5. a diminuição da microdureza e o desgaste resultantes da aplicação do jato de bicarbonato de sódio são reparados em no máximo 24 horas, após o procedimento. 
Anexos

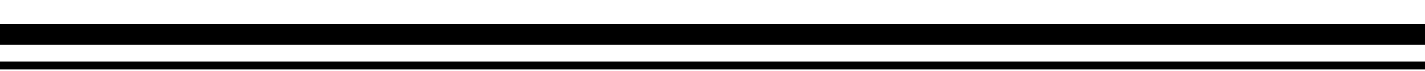




\section{Anexos}

ANEXO 1 - Valores em KHN das 5 medidas e da média da microdureza superficial inicial de cada espécime

\begin{tabular}{|c|c|c|c|c|c|c|}
\hline$N$ & $1^{a}$ & $2^{a}$ & $3^{a}$ & $4^{a}$ & $5^{a}$ & Média \\
\hline 1 & 376 & 408 & 347 & 395 & 388 & 383 \\
\hline 2 & 332 & 388 & 395 & 364 & 401 & 376 \\
\hline 3 & 388 & 353 & 358 & 337 & 299 & 347 \\
\hline 4 & 370 & 283 & 347 & 303 & 244 & 309 \\
\hline 5 & 342 & 382 & 364 & 358 & 395 & 368 \\
\hline 6 & 401 & 408 & 382 & 347 & 401 & 388 \\
\hline 7 & 332 & 382 & 388 & 299 & 401 & 360 \\
\hline 8 & 347 & 429 & 342 & 322 & 382 & 364 \\
\hline 9 & 342 & 295 & 275 & 342 & 257 & 315 \\
\hline 10 & 401 & 299 & 317 & 364 & 382 & 353 \\
\hline 11 & 401 & 299 & 317 & 364 & 382 & 353 \\
\hline 12 & 342 & 415 & 401 & 312 & 364 & 367 \\
\hline 13 & 388 & 358 & 408 & 376 & 347 & 375 \\
\hline 14 & 395 & 322 & 358 & 429 & 364 & 374 \\
\hline 15 & 415 & 382 & 312 & 332 & 382 & 365 \\
\hline MF & & & & & & 359,80 \\
\hline
\end{tabular}


ANEXO 2 - Valores em KHN das 5 medidas e da média da microdureza superficial de cada espécime, após tratamento com jato de bicarbonato de sódio

\begin{tabular}{|c|c|c|c|c|c|c|}
\hline$N$ & $1^{a}$ & $2^{a}$ & $3^{a}$ & $4^{a}$ & $5^{a}$ & Média \\
\hline 1 & 347 & 295 & 342 & 415 & 408 & 361 \\
\hline 2 & 347 & 358 & 317 & 347 & 370 & 348 \\
\hline 3 & 347 & 415 & 376 & 364 & 364 & 374 \\
\hline 4 & 303 & 250 & 240 & 337 & 271 & 280 \\
\hline 5 & 422 & 353 & 327 & 382 & 358 & 368 \\
\hline 6 & 395 & 388 & 401 & 388 & 347 & 384 \\
\hline 7 & 327 & 358 & 275 & 303 & 317 & 316 \\
\hline 8 & 327 & 264 & 322 & 388 & 207 & 302 \\
\hline 9 & 382 & 347 & 415 & 358 & 353 & 371 \\
\hline 10 & 364 & 299 & 279 & 364 & 291 & 319 \\
\hline 11 & 327 & 260 & 275 & 299 & 308 & 294 \\
\hline 12 & 364 & 299 & 370 & 308 & 322 & 332 \\
\hline 13 & 271 & 376 & 342 & 388 & 401 & 356 \\
\hline 14 & 317 & 317 & 279 & 271 & 327 & 302 \\
\hline 15 & 283 & 322 & 353 & 332 & 337 & 325 \\
\hline MF & & & & & & 335,46 \\
\hline
\end{tabular}


ANEXO 3 - Valores em KHN das 5 medidas e da média da microdureza superficial de cada espécime, após 1 hora de imersão em saliva artificial

\begin{tabular}{|c|c|c|c|c|c|c|}
\hline$N$ & $1^{a}$ & $2^{a}$ & $3^{a}$ & $4^{a}$ & $5^{a}$ & Média \\
\hline 1 & 347 & 422 & 382 & 364 & 376 & 378 \\
\hline 2 & 422 & 370 & 376 & 401 & 358 & 385 \\
\hline 3 & 401 & 364 & 342 & 408 & 364 & 376 \\
\hline 4 & 422 & 364 & 279 & 283 & 317 & 333 \\
\hline 5 & 299 & 260 & 226 & 376 & 364 & 305 \\
\hline 6 & 429 & 437 & 353 & 312 & 395 & 385 \\
\hline 7 & 422 & 370 & 337 & 347 & 370 & 369 \\
\hline 8 & 342 & 415 & 353 & 342 & 376 & 365 \\
\hline 9 & 382 & 376 & 401 & 429 & 347 & 387 \\
\hline 10 & 347 & 364 & 388 & 388 & 358 & 369 \\
\hline 11 & 388 & 347 & 332 & 308 & 322 & 339 \\
\hline 12 & 376 & 342 & 429 & 388 & 408 & 389 \\
\hline 13 & 415 & 358 & 395 & 317 & 415 & 380 \\
\hline 14 & 422 & 401 & 395 & 401 & 429 & 410 \\
\hline 15 & 395 & 312 & 445 & 353 & 337 & 368 \\
\hline MF & & & & & & 369,20 \\
\hline
\end{tabular}


ANEXO 4 - Valores em KHN das 5 medidas e da média da microdureza superficial de cada espécime, após 24 horas de imersão em saliva artificial

\begin{tabular}{|c|c|c|c|c|c|c|}
\hline$N$ & $1^{a}$ & $2^{a}$ & $3^{a}$ & $4^{a}$ & $5^{a}$ & Média \\
\hline 1 & 358 & 415 & 395 & 395 & 415 & 395 \\
\hline 2 & 422 & 415 & 388 & 342 & 342 & 382 \\
\hline 3 & 376 & 353 & 342 & 370 & 461 & 380 \\
\hline 4 & 303 & 332 & 388 & 353 & 287 & 332 \\
\hline 5 & 332 & 364 & 370 & 376 & 388 & 366 \\
\hline 6 & 408 & 408 & 395 & 408 & 382 & 400 \\
\hline 7 & 388 & 337 & 370 & 317 & 347 & 352 \\
\hline 8 & 401 & 401 & 422 & 408 & 376 & 402 \\
\hline 9 & 332 & 382 & 342 & 382 & 388 & 365 \\
\hline 10 & 408 & 342 & 376 & 342 & 445 & 382 \\
\hline 11 & 287 & 401 & 299 & 299 & 280 & 349 \\
\hline 12 & 388 & 382 & 437 & 408 & 382 & 399 \\
\hline 13 & 422 & 415 & 401 & 342 & 382 & 392 \\
\hline 14 & 364 & 429 & 422 & 376 & 395 & 397 \\
\hline 15 & 353 & 395 & 408 & 317 & 395 & 373 \\
\hline MF & & & & & & 377,73 \\
\hline
\end{tabular}


ANEXO 5 - Valores em KHN das 5 medidas e da média final da microdureza superficial de cada espécime, após 7 dias de imersão em saliva artificial

\begin{tabular}{|c|c|c|c|c|c|c|}
\hline$N$ & $1^{a}$ & $2^{a}$ & $3^{a}$ & $4^{a}$ & $5^{a}$ & Média \\
\hline 1 & 422 & 364 & 308 & 347 & 395 & 367 \\
\hline 2 & 347 & 376 & 303 & 382 & 364 & 354 \\
\hline 3 & 382 & 303 & 370 & 395 & 299 & 350 \\
\hline 4 & 327 & 295 & 231 & 303 & 312 & 294 \\
\hline 5 & 364 & 353 & 353 & 308 & 358 & 347 \\
\hline 6 & 342 & 382 & 452 & 303 & 342 & 364 \\
\hline 7 & 264 & 308 & 376 & 388 & 312 & 330 \\
\hline 8 & 415 & 347 & 317 & 370 & 303 & 350 \\
\hline 9 & 376 & 353 & 299 & 332 & 347 & 341 \\
\hline 10 & 312 & 337 & 353 & 291 & 370 & 332 \\
\hline 11 & 267 & 253 & 247 & 308 & 303 & 276 \\
\hline 12 & 358 & 327 & 376 & 422 & 337 & 364 \\
\hline 13 & 370 & 388 & 395 & 327 & 358 & 368 \\
\hline 14 & 327 & 327 & 376 & 327 & 370 & 345 \\
\hline 15 & 342 & 332 & 247 & 408 & 401 & 346 \\
\hline MF & & & & & & 341,86 \\
\hline
\end{tabular}


ANEXO 6 - Valores em $\mu$ m das 5 medidas do desgaste de cada espécime após a simulação da profilaxia.

\begin{tabular}{|c|c|c|c|c|c|}
\hline $\bar{N}$ & $1^{a}$ & $2^{a}$ & $3^{a}$ & $4^{a}$ & $5^{a}$ \\
\hline 1 & 0,392 & 0,663 & 0,490 & 0,413 & 0,367 \\
\hline 2 & 0,787 & 0,862 & 0,671 & 0,696 & 0,3887 \\
\hline 3 & 0,439 & 0,762 & 0,700 & 0,706 & 0,3564 \\
\hline 4 & 0,484 & 0,645 & 0,656 & 0,679 & 0,549 \\
\hline 5 & 0,676 & 0,854 & 0,409 & 0,929 & 0,671 \\
\hline 6 & 0,720 & 0,693 & 0,701 & 0,730 & 0,620 \\
\hline 7 & 0,383 & 0,470 & 0,404 & 0,426 & 0,485 \\
\hline 8 & 0,457 & 0,396 & 0,378 & 0,409 & 0,485 \\
\hline 9 & 0,428 & 0,576 & 0,286 & 0,627 & 0,691 \\
\hline 10 & 0,574 & 0,658 & 0,491 & 0,409 & 0,692 \\
\hline 11 & 0,559 & 0,530 & 0,646 & 0,653 & 0,673 \\
\hline 12 & 0,415 & 0,337 & 0,490 & 0,507 & 0,573 \\
\hline 13 & 0,459 & 0,496 & 0,650 & 0,444 & 0,606 \\
\hline 14 & 0,465 & 0,512 & 0,498 & 0,613 & 0,610 \\
\hline 15 & 0,369 & 0,662 & 0,272 & 0,563 & 0,566 \\
\hline MF & & & & & 0,564 \\
\hline
\end{tabular}


ANEXO 7 - Valores em $\mu$ m das 5 medidas do desgaste de cada espécime após 1 hora de imersão em saliva artificial

\begin{tabular}{|c|c|c|c|c|c|}
\hline $\bar{N}$ & $1^{a}$ & $2^{a}$ & $3^{a}$ & $4^{a}$ & $5^{a}$ \\
\hline 1 & 0,550 & 0,444 & 0,610 & 0,673 & 0,536 \\
\hline 2 & 0,564 & 0,599 & 0,576 & 0,375 & 0,378 \\
\hline 3 & 0,605 & 0,497 & 0,438 & 0,513 & 0,771 \\
\hline 4 & 0,430 & 0,645 & 0,620 & 0,570 & 0,510 \\
\hline 5 & 0,414 & 0,364 & 0,338 & 0,409 & 0,431 \\
\hline 6 & 0,817 & 0,719 & 0,696 & 0,811 & 0,583 \\
\hline 7 & 0,412 & 0,423 & 0,370 & 0,407 & 0,420 \\
\hline 8 & 0,494 & 0,441 & 0,399 & 0,759 & 0,383 \\
\hline 9 & 0,529 & 0,481 & 0,564 & 0,435 & 0,632 \\
\hline 10 & 0,576 & 0,661 & 0,767 & 0,478 & 0,590 \\
\hline 11 & 0,312 & 0,559 & 0,352 & 0,461 & 0,324 \\
\hline 12 & 0,415 & 0,484 & 0,484 & 0,421 & 0,444 \\
\hline 13 & 0,320 & 0,450 & 0,490 & 0,475 & 0,420 \\
\hline 14 & 0,683 & 0,696 & 0,630 & 0,765 & 0,740 \\
\hline 15 & 0,429 & 0,429 & 0,441 & 0,536 & 0,488 \\
\hline MF & & & & & 0,519 \\
\hline
\end{tabular}


ANEXO 8 - Valores em $\mu \mathrm{m}$ das 5 medidas do desgaste de cada espécime após 24 horas de imersão em saliva artificial

\begin{tabular}{|c|c|c|c|c|c|}
\hline$N$ & $1^{a}$ & $2^{a}$ & $3^{a}$ & $4^{a}$ & $5^{a}$ \\
\hline 1 & 0,301 & 0,272 & 0,301 & 0,461 & 0,444 \\
\hline 2 & 0,398 & 0,547 & 0,582 & 0,605 & 0,520 \\
\hline 3 & 0,509 & 0,397 & 0,437 & 0,478 & 0,515 \\
\hline 4 & 0,399 & 0,515 & 0,509 & 0,430 & 0,470 \\
\hline 5 & 0,536 & 0,736 & 0,784 & 0,797 & 0,719 \\
\hline 6 & 0,358 & 0,381 & 0,370 & 0,530 & 0,438 \\
\hline 7 & 0,379 & 0,353 & 0,315 & 0,399 & 0,407 \\
\hline 8 & 0,456 & 0,441 & 0,432 & 0,593 & 0,437 \\
\hline 9 & 0,358 & 0,289 & 0,421 & 0,438 & 0,415 \\
\hline 10 & 0,393 & 0,375 & 0,467 & 0,444 & 0,397 \\
\hline 11 & 0,289 & 0,319 & 0,352 & 0,320 & 0,280 \\
\hline 12 & 0,358 & 0,444 & 0,289 & 0,393 & 0,415 \\
\hline 13 & 0,315 & 0,380 & 0,415 & 0,320 & 0,435 \\
\hline 14 & 0,540 & 0,479 & 0,519 & 0,560 & 0,409 \\
\hline 15 & 0,519 & 0,375 & 0,370 & 0,576 & 0,520 \\
\hline MF & & & & & 0,441 \\
\hline
\end{tabular}


ANEXO 9 - Valores em $\mu \mathrm{m}$ das 5 medidas do desgaste de cada espécime após 7 dias de imersão na saliva artificial

\begin{tabular}{|c|c|c|c|c|c|}
\hline$N$ & $1^{a}$ & $2^{a}$ & $3^{a}$ & $4^{a}$ & $5^{a}$ \\
\hline 1 & 0,438 & 0,490 & 0,570 & 0,536 & 0,467 \\
\hline 2 & 0,668 & 0,520 & 0,510 & 0,575 & 0,508 \\
\hline 3 & 0,352 & 0,358 & 0,398 & 0,341 & 0,375 \\
\hline 4 & 0,398 & 0,470 & 0,435 & 0,470 & 0,452 \\
\hline 5 & 0,524 & 0,547 & 0,553 & 0,520 & 0,542 \\
\hline 6 & 0,479 & 0,542 & 0,415 & 0,496 & 0,450 \\
\hline 7 & 0,301 & 0,325 & 0,242 & 0,315 & 0,353 \\
\hline 8 & 0,438 & 0,536 & 0,398 & 0,479 & 0,467 \\
\hline 9 & 0,484 & 0,473 & 0,456 & 0,524 & 0,490 \\
\hline 10 & 0,341 & 0,410 & 0,421 & 0,315 & 0,438 \\
\hline 11 & 0,375 & 0,245 & 0,358 & 0,315 & 0,320 \\
\hline 12 & 0,353 & 0,380 & 0,250 & 0,375 & 0,385 \\
\hline 13 & 0,280 & 0,320 & 0,358 & 0,375 & 0,370 \\
\hline 14 & 0,415 & 0,389 & 0,475 & 0,430 & 0,490 \\
\hline 15 & 0,542 & 0,398 & 0,398 & 0,501 & 0,370 \\
\hline MF & & & & & 0,428 \\
\hline
\end{tabular}




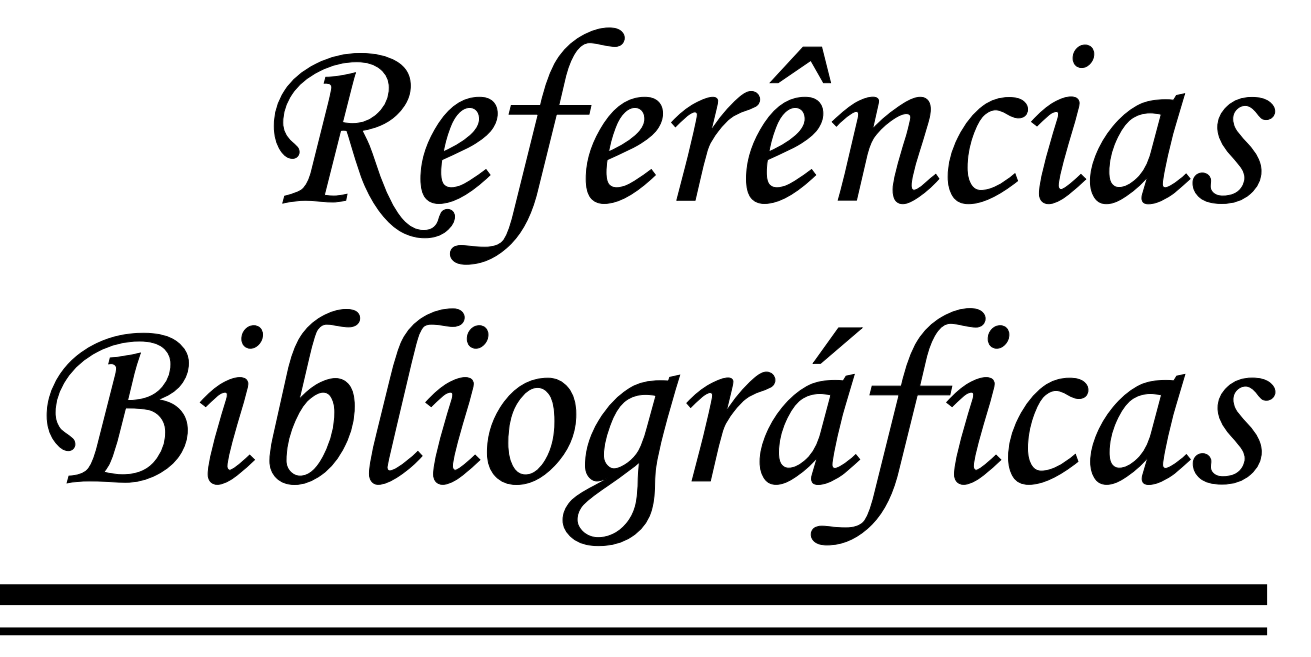




\section{Referências Bibliográficas}

1. AGGER, M. S.; HOSTED-BINDSLEV, P.; HOVGAARD, O. Abrasiveness of an air-powder polishing system on root surfaces in vitro. Quintessence Int, v.2, n.5, p.407-11, May 2001.

2. AMAECHI, B. T.; HIGHAM. In vitro remineralization of eroded lesions by saliva. J Dent , v.29, n.5, p.371-6, July 2001.

3. AMAECHI, B. T.; HIGHAM. Eroded enamel lesion remineralization by saliva as a possible factor in the site-specificity of human dental erosion. Arch Oral Biol, v.46, n.8, p.697-703, Aug. 2001.

4. AMAECHI, B. T.; HIGHAM, S. M.; EDGAR, W. M. Factors influencing the development of dental erosion in vitro: enamel type, temperature and exposure time. J Oral Rehabil, v. 26, n. 8, p. 624-30, Aug. 1999.

5. AMAECHI, B. T.; HIGHAM, S. M.; EDGAR, W. M. Techniques for the production of dental eroded lesions in vitro. J Oral Rehabil, v. 26, n. 2, p. 97-102, Feb. 1999.

6. ARENDS, J.; SCHUTHOF, J.; JONGEBLOED, W. G. Lesion depth and microhardness indentations on artificial white spot lesions. Caries Res, v. 14 , n. 4 , p. $190-5,1980$.

\footnotetext{
* Normas recomendadas para uso no âmbito da Universidade de São Paulo, com base no documento "Referências Blbliográficas: exemplos", emanado do Conselho supervisor do Sistema Integrado de Bibliotecas da USP, em reunião de 20 de setembro de 1990.
} 
7. ARENDS, J.; SCHUTHOF, J.; JONGEBLOED, W. G. Microhardness indentations on artificial white spot lesions. Caries Res, v. 13, n. 5, p. 290-7, 1979.

8. ARNOLD, W. H. et al. Induction and $3 \mathrm{D}$ reconstruction of caries-like lesions in an experimental dental plaque biofilm model. J Oral Rehabil, v.28, n.8, p.748-54, Aug. 2001.

9. ATTIN, T. et al. Correlation of microhardness and wear in differently eroded bovine dental enamel. Arch Oral Biol, v.42, n.3, p.243-50, Mar. 1997.

10. ATTIN, T. et al. Use of remineralization periods to improve the abrasion resistance of previously eroded enamel. Caries Res, v.33, n.1, p.4852, Jan./Feb. 2000.

11. ATKINSON, D.R.; COBB, C.M.; KILLOY, W.J. The effect of an airpowder abrasive system on in vitro root surfaces. J Periodont, v.55, n.1, p.13-8, Jan. 1984.

12. AXELSSON, P.; LINDHE, J.; NYSTROM, B. On the prevention of caries and periodontal disease. Results of a 15-year longitudinal study in adults. J Clinical Periodont, v.18, n.3, p.182-9, Mar. 1991.

13. AXELSSON, P.; LINDHE, J.; WASEBY, J. The effect of various plaque control measures on gingivitis and caries in schoolchildren. Community Dent Oral Epidemiol, v.4, n.6, p.232-9, Nov. 1976.

14. BARBAKOW, F.; LUTZ, F.; IMFELD, T. Relative dentin abrasion by dentifrices and prophylaxis pastes: implications for clinicans, manufactures and patients. Quintessence Int, v.18, n.1, p.29-34, Jan. 1987. 
15. BELLINI, H.T.; ARNENBERG, P.; VON DER FEHR, F.R. Oral hygiene and caries. A review. Acta Odont Scand, v.39, n.5, p. 257-65, Sept./Oct. 1981.

16. BOYDE, A. Airpolishing effects on enamel, dentine, cement and bone. Brit Dent J, v.156, n.8, p.287-91, Apr. 1984.

17. BUSKES, J.A.K.M.; CHRISTOFFERSEN, J.; ARENDS, J. Lesions formation remineralization in enamel under constant composition conditions. Caries Res, v.19, n.6, p.490-6, 1985.

18. CALDWELL, R.C. et al. Microhardness studies of intact surface enamel. J Dent Res, v.36, n.5, p.732-8, Oct. 1957.

19. CALDWELL, R.C. et al. Semiquantitative studies of in vitro caries by microhardness tests. J Dent Res, v37, n.2, p.301-5, Apr. 1958.

20. CHRISTENSEN, R.P.; BANGERTER, V.W. Immediate and long-term in vivo effects of polishing on enamel and dentin. J Prosth Dent, v.57, n.2, p.150-60, Feb. 1987.

21. COLLYS, K. et al. Load dependency and reliability of microhardness mesurements on acid-etched enamel surfaces. Dent Mat, v.8, n.5, p.332-5, Sept. 1992.

22. CRAIG, R.G.; PEYTON, F.A. The microhardness of enamel dentin. J Dent Res, v.37, n.4, p.661-8, Aug. 1958.

23. DAVIDSON, C.L.; HOEKSTRA, I.S.; ARENDS, J. Microhardness of sound, decalcified and etched yooth enamel related to the calcium content. Caries Res, v.8, n.2, p.135-44, 1974. 
24. DAVIS, W.B.; WINTER, P.J. Measurement in vitro of enamel abrasion by dentifrice. J Dent Res, v.55, n.6, p.970-5, Nov./Dec. 1976.

25. DE SPAIN, B.; NOBIS, R. A comparison of rubber cup polishing and air polishing. J Dent Res, v.66, p.151, 1987. Abstract n.347

26. FEAGIN, F.; KOULOURIDES, T.; PIGMAN, W. The characterization of enamel surface demineralization, remineralization, and associated hardness changes in human and bovine material. Arch Oral Biol, v.14, n.12, p.1407-17, Dec. 1969.

27. FEATHERSTONE, J.D.B. et al. Comparasion of artificial caries-like lesion by quantitative microradiography and microhardness profiles. Caries Res, v.17, n.5, p.385-91, Sept./Oct. 1983.

28. FEATHERSTONE, J.D.; MELLBERG, J.R. Relative rates of progress of artificial lesions in bovine, ovine and human enamel. Caries Res, v.15, n.1, p.109-14, 1981.

29. FRAGA, A.C.A. Avaliação "in vitro" do efeito da profilaxia com jato de bicarbonato de sódio sobre o esmalte hígido e com lesão de cárie artificial e posterior remineralização. Bauru, 2005. 95p. Dissertação (Mestrado). Faculdade de Odontologia de Bauru Universidade de São Paulo.

30. FREITAS, P. M. de et al. Dentin microhardness during and after whitening treatments. Quintessence Int, v.35, n.6, p.411-7, May 2004.

31. GALLOWAY, S.E.; PASHLEY, D.H. Rate of removal of root structure by the use of the Prophy-Jet device. J Periodont, v.58, n.7, p.464-9, July 1987. 
32. GERBO, L. R. et al. Enamel roughness after air powder polishing. Am J Dent, v.6, n.2, p.96-8, Apr. 1993.

33. GRABENSTETTER, R.J. et al. The mesurement of abrasion of human teeth by dentifrice abrasives: a test utilizing radiactive teeth. J Dent Res, v.37, n.6.p.1060-8, Nov./Dec. 1958.

34. HEAD, J. A study of saliva and its action on tooth enamel in reference to its hardening and softening. J Am Med Ass, v.59, p.2118-22, Dec. 1912.

35. HEFFERREN, J.J. A laboratory method for assesment of dentifrice abrasivity. J Dent Res, v.55, n.4, p.563-73, July / Aug. 1976.

36. HODGE, H.C. Hardness tests on teeth. J Dent Res, v.20, n.5, p.271-9, May 1936.

37. HODGE, H.C.; MICKAY, H. The microhardness of teeth. J Am Dent Assoc, v.20, n.2, p.227-33, Feb. 1933.

38. HOLLERON, B. W.; PORTEOUS, N. B.; AMAECHI, B. T. Treating caries as a disease and restoring carious teeth via remineralization. Tex Dent J, v.120, n.10, p.946-57, Oct. 2003.

39. HOLMEN, L. et al. The effect of regular professional plaque removal on dental caries in vivo. A polarized light and scanning electron microscope study. Caries Res, v.22, n.4, p.250-6, 1988. 
40. HONÓRIO, H. M. Avaliação do desgaste de diferentes métodos de profilaxia sobre o esmalte bovino hígido e desmineralizado. Bauru, 2003. 154p. Dissertação (Mestrado) - Faculdade de Odontologia de Bauru, Universidade de São Paulo.

41. HOSOYA, Y. et al. Microhardness of carious deciduous dentin. Oper Dent, v.26, n.2, p.81-9, Mar./Apr. 2000.

42. HOSOYA, Y.; JOHNSTON, J. W. Evaluation of various cleaning and polishing methods on primary enamel. J Pedod, v.13, n.3, p.253-69, 1989.

43. JOHANSSON, B. Remineralization of slightly etched enamel. J Dent Res, v.44, n.1, p.64-70, Jan. 1965.

44. KARLSTRÖM, S. A scleroscopic investigation of the enamel teeth. Svensk Tandläk Tydsk, v.20, p.201-17, 1927 apud NEWBRUN, E.; PIGMAN, W. The hardness of enamel and dentine. Aust Dent J, v.5, n.4, p.210-7, Aug. 1960.

45. KIELBASSA, A. M. et al. Irradiation effects on microhardness of fluoridated non-fluoridated bovine dentin. Eur J Oral Sci, v.105, n.5, p.444-7, Oct. 1997.

46. KIELBASSA, A. M. et al. Correlation of transversal microradiography and microhardness on in situ-induced demineralization in irradiate and nonirradiated human enamel. Arch Oral Biol, v.44, n.3, p.243-51, Mar. 1999. 
47. KNOOP, F.; PETERS, G.C.; EMERSON, W.B. A sensitive pyramidal diamond tool for indentation measurements. J Res Nat Bur Stds, v.23, p.39-61, 1939 apud NEWBRUN, E.; PIGMAN, W. The hardness of enamel dentine. Aust Dent J, v.5, n.4, p.210-7, Aug. 1960.

48. KRAMER, P.F.; FELDENS, C.A.; ROMANO, A.R. Promoção de saúde bucal em Odontopediatria. São Paulo, Artes Médicas, 1997.

49. LIMA, J. E. O. Um plano de prevenção para consultório odontopediátrico. Rev Gaúcha Odontol, v. 40, n. 6, p. 395-9, nov./dez.1992.

50. LIMA, S.N.M.; VERRI, R.A. Efeitos da aplicação de bicarbonato de sódio sob pressão no tratamento básico periodontal e na remoção de placa bacteriana. Rev Paul Odontol, v.6, n.1, p. 2-10, jan./fev. 1984.

51. LENZ, $H$. Ultrastructure of tooth in respect of mineralization, demineralization and remineralization. Int Dent J, v.17, n.4, p.693708, Dec. 1967.

52. LUSSI, A. et al. A comparison of the erosive potential of different beverages in primary and permanent teeth using an in vitro model. Eur J Oral Sci, v.108, n.2, p.110-4, Apr. 2000.

53. LUTZ, F.; IMFELD, T. Advances in abrasiveness: a new technology prophylaxis pastes. Comp Continuing Educ Dent, v.23, n.1, p.6170, Jan. 2002.

54. MANNING, R.H.; EDGAR, W. M. Intra-oral models for studying de- and remineralization in man: methodology and measurement. $\mathbf{J}$ Dent Res, v 71, p.895-900, Apr. 1992. Special Issue. 
55. MARTA, S. N. Avaliação do efeito do jato de bicarbonato de sódio no esmalte de dentes permanentes jovens. Bauru, 1997. 81p. Dissertação (Mestrado) - Faculdade de Odontologia de Bauru, Universidade de São Paulo.

56. MARTA, S. N. Avaliação in situ do efeito de dentifrícios com e sem flúor associados ou não à profilaxia profissional com jato de bicarbonato de sódio sobre a remineralização do esmalte dental. Bauru, 2002. 139 p. Tese (Doutorado) - Faculdade de Odontologia de Bauru, Universidade de São Paulo.

57. MELLBERG, J.R. Hard-tissue substrates for evaluation of cariogenic and anti cariogenic activity in situ. J Dent Res, v.71, p.913-9, Apr. 1992. Special Issue.

58. MISHKIN, D. J. et al. A clinical comparison of the effect on the gingival of the prophy-jet and the rubber cup and paste techniques. J Periodont, v.57, n.3, p.151-4, Mar. 1986.

59. NEWBRUN, E.; PIGMAN, W. The hardness of enamel and dentine. Aust Dent J, v.5, n.4, p.210-7, Aug. 1960.

60. NEWBRUN, E.; TIMBERLAKE, P.; PIGMAN, W. Changes microhardness of enamel following treatment with lactate buffer. J Dent Res, v.38, n.2, p.293-300, Mar./Apr. 1959.

61. NEWMAN, P. S.; SILVERWOOD, R. A.; DOLBY, A. E. The effects of an air abrasive instrument on dental hard tissues, skin and oral mucosa. Brit Dent J, v.159, n.1, p.9-12, July 1985. 
62. NUNES, A. C. R. Avaliação do efeito remineralizador da saliva artificial, associada ou não a dentifrícios fluoretados, no processo de desmineralização provocado por ciclagens de $\mathrm{pH}$, em esmalte bovino. Bauru, 2002. 144 p. Dissertação (Mestrado) Faculdade de Odontologia de Bauru, Universidade de São Paulo.

63. NUTI SOBRINHO, A. et al. Estudo da ação do sistema Profident sobre a placa bacteriana em bandas ortodônticas através da microscopia eletrônica de varredura. Rev Paul Odontol, v.7, n.3, p.10-7, maio/ jun. 1986.

64. NUTI SOBRINHO, A.; LIMA, S.N.M.; WATANABE, I. Estudo da ação do Profident sobre a placa bacteriana dental através da microscopia eletrônica de varredura. Rev Paul Odontol, v.7, n.2, p.34-59, mar./ abr. 1985.

65. OESTERLE, L. J. et al. The use of bovine enamel in bonding studies. Am J Orthod Dentofacial Orthop, v.144, n.5, p.514-9, Nov. 1998.

66. ÖGAARD, B.; TEN BOSCH, J.J. Regression of white spot enamel lesions. A new optical method for quantitative longitudinal evaluation in vivo. Am J Dentof Orthop, v.106, n.3, p.238-42, Sept. 1994.

67. PANG, D.T.Y.; VANN JR, W.F. The use of fluoride-containig toothpaste in young children: the scientific evidence for recommending a small quantity. Pediatric Dent, v.14, n.6, p.384-7, Nov./Dec. 1992.

68. PERETZ, B.; SANART, H.; MOSS, S. J. Caries protective aspects of saliva and enamel. N Y State Dent J, v.56, n.1, p.25-7, Jan. 1990.

69. PETERSSON, L.G. et al. The effect of a jet abrasive instrument (Prophy Jet) on root surfaces. Swed Dent J, v.9, n.5, p.193-9, 1985. 
70. PHILLIPS R.W.; SWARTZ, M.L. Effect of fluorides on hardness of tooth enamel. J Amer Dent Ass, v.37, n.1, p.1-13, July 1948.

71. PICKERILL, H.P. The prevention of dental caries and oral sepsis. Londres, Baillière, Tindall \& Cox, 1912 apud NEWBRUN, E.; PIGMAN, W. The hardness of enamel and dentine. Aust Dent J, v.5, n.4, p.2107, Aug. 1960.

72. PRIMOSCH, R.E. Rubber cup prophylaxis: a reevaluation of its use in pediatric dental patients. Dental Hyg, v.54, n. 11, p. 525-7n Nov. 1980.

73. PURDELL-LEWIS, D. J.; GROENVELD, A.; ARENDS, J. Hardeness tests on sound enamel and artificially demineralized white spot lesions. Caries Res, v.10, n.3, p.201-15, 1976.

74. RAMAGLIA, L. et al. A clinical comparasion of efficacy and efficiency of two professional profhylaxis procedures in orthodontic patients. Europ J Orthod, v.21, n.4, p.423-8, Aug. 1999.

75. RIOS, D. Avaliação in situ do efeito erosivo de um refrigerante associado ou não à escovação e ação salivar em dentes humanos e bovinos. Bauru, 2004. 215 p. Tese (Doutorado) Faculdade de Odontologia de Bauru, Universidade de São Paulo.

76. SATO, I. et al. Comparison between deciduous and permanent incisor teeth in morphology of bovine enamel. Okajimas Folia anat Jap, v.76, n.2-3, p.131-5, 1999.

77. SILVERSTONE, L.M. Remineralization phenomena. Caries Res, v.11, p.59-84, 1977b. Supplement 1. 
78. SILVERSTONE, L.M.; POODLE, D.F.G. Histologic and ultrastructural features of remineralized carious enamel. J Dent Res, v.48, n.5, p.766-70, May 1969.

79. SOUDER, W.; SCHOONOVER, I.C. Abrasion and solution of teeth: a sensitive, visual method for detecting these injuries. J Am Dent Assoc, v.30, n.20, p.1725-34, Nov. 1943.

80. STOOKEY, G.K. In vitro estimates of enamel and dentin abrasion associated with a prophylaxis. J Dent Res, v.57, n.1, p.36, Jan. 1978.

81. STOOKEY, G.K. Review of fluorosis risk of self applied topical fluorides: dentifrices, mouthrinswes and gels. Community Dent Oral Epidemiol, v.22, n.3. p.181-6, Jun. 1994.

82. STRAND, G.V.; RAADAL, M. The efficiency of cleaning fissures with an air -polishing instrument. Acta Odont Scand, v.46, n.2, p.113-7, Apr. 1988.

83. WEAKS, L.M. et al. Clinical evaluation of the Prophy-Jet as an instrument forroutine removal of tooth stain and plaque. J Periodont, v.55, n.8, p. 486-8, Aug. 1984.

84. WHITE, D.J. Reactivity of fluoride dentifrices with artificial caries. Effects on early lesions: $F$ uptake, surface hardening an remineralizations. Caries Res, v.21, n.2, p.126-40, Mar./Apr. 1987.

85. WILLMANN, D.E.; NORLING, B.K.; JOHNSON, W.N. A new prophylaxis instrument: effect on enamel alterations. J Am Dent Assoc, v.101, n.6, p.923-5, Dec. 1980. 
86. WILSON, M. Bactericidal effect of laiser light and its potential use in the treatment of plaque-related diseases. Int Dent J, v.44, n.2., p.181-9, Apr. 1994.

87. WINSTON, A. E.; BHASKAR, S. N. Caries prevention in the $21 \mathrm{st}$ century. J Am Dent Assoc, v.129, n.11, p.1579-87, Nov. 1998.

88. VRBIC, V.; BRUDEVOLD, F.;McCANN, H.G. Acquisition of fluoride by enamel from fluoride pumice pastes. Helv Odont Acta, v.11, p.21-6, Apr. 1967.

89. ZERO, D.T. In situ caries models. Adv Dent Res, v.9, n.3, p.214-30, Nov. 1995.

90. ZERO, D.T. et al. Comparasion of the iodide permeability test, the surface microhardness test and mineral dissolution of bovine enamel following acid chalenge. Caries Res, v. 24, n.3, p.181-8, May/June 1990.

91. ZUNIGA, M.A.; CALDWELL, R.C. Pastes on normal and "white-spot" enamel: the effect of fluoride-containig prophylaxis. ASDC $\mathbf{J}$ Dent Child, v.36, n. 5, p.55-9, Sept./Oct. 1969. 


\section{Abstract}

\section{Evaluation of the professional prophylaxis effect with sodium bicarbonate jet on bovine tooth enamel and the remineralizing effect of artificial saliva. An In vitro study}

The purpose of this study was to evaluate, in vitro, the alterations caused by the sodium bicarbonate jet on the sound bovine enamel and the further remineralizing effect of artificial saliva in different time periods. Fifteen enamel samples $(4,0 \mathrm{~mm} \times 4,0 \mathrm{~mm})$ were used, which constituted the groups MI (no treatment), MII (treatment with sodium bicarbonate jet), MIII (treatment with sodium bicarbonate jet and immersion in saliva for one hour), MIV (treatment with sodium bicarbonate jet and immersion in saliva for 24 hours), MV (treatment with sodium bicarbonate jet and immersion in saliva for 7 days) and DI (treatment with sodium bicarbonate jet), DII (treatment with sodium bicarbonate jet and immersion in saliva for one hour), DIII (treatment with sodium bicarbonate jet and immersion in saliva for 24 hours) and DIV (treatment with sodium bicarbonate jet and immersion in saliva for 7 days). Following treatment with sodium bicarbonate jet, the samples were immersed in $20 \mathrm{ml}$ artificial saliva, individually stored in buffered plastic vials, in klin at $37^{\circ} \mathrm{C}$, by the above mentioned periods of time. The saliva was renewed every day. Microhardness tests were carried out using a microdurometer and wear tests by a rugosimeter. The data were assessed by the one criterion variance analysis and Tukey test. The mean value of microhardness, in KHN, in groups MI, MII, MIII, MIV and MV were 359,80; 335,46; 369,20; 377,73 and 341,86 , respectively, whereas the mean values in $\mu \mathrm{m}$, of wear for group DI, DII, DIII and DIV were 0,564; 0,519; 0,441 and 0,428, respectively. It was concluded that: the sodium bicarbonate jet caused a wear and a reduction in microhardness on the enamel surface; saliva promoted the recovery of initial condition surface microhardness and reduced the wear; the repairing effect 
of saliva on the surface microhardness alterations occurred within on hour of treatment, having no significant statistical difference from the effect obtained in 24 hours; the best saliva repairing effect on the wear occurred with treatment of 24 hours. 